\title{
GROWTH AND STRUCTURAL CHANGE IN SPAIN, 1850-2000: A EUROPEAN PERSPECTIVE +*
}

\author{
LEANDRO PRADOS DE LA ESCOSURA ${ }^{a}$ \\ Universidad Carlos III de Madrid
}

\begin{abstract}
RESUMEN
En este ensayo se examina el progreso económico a largo plazo de la España contemporánea y se sitúa en perspectiva europea. En siglo y medio, la renta per capita aumentó quince veces. Tres grandes fases pueden distinguirse: 1850-1950, 1951-1974 y 1975-2000. El peor comportamiento relativo de España en el largo plazo se debió fundamentalmente al lento crecimiento durante etapas concretas del siglo anterior a 1950. En la segunda mitad del siglo xx, y en particular, durante 1959-1974, España acortó distancias. El cambio estructural contribuyó significativamente a la aceleración del crecimiento, en tanto la falta de exposición a la competencia internacional constituyó un elemento recurrente de atraso.
\end{abstract}

Palabras clave: crecimiento largo plazo, cambio estructural, convergencia, España, Europa

+ Written to honour Gabriel Tortella in his seventieth birthday.

* Received on $5^{\text {th }}$ March 2007. I am grateful to Stephen Broadberry, Alan Dye, Riitta Hjerppe, Angus Maddison, and Isabel Sanz-Villarroya for their comments. An earlier version of the paper was presented at the Vice-Presidential Session on «Convergence and Nonconvergence since the Second World War», International Economic History Association Congress (Helsinki August, 2006). The usual disclaimer applies.

a Departamento de Historia Económica e Instituciones, Universidad Carlos III de Madrid, c/ Madrid, 126, 28903 Getafe, Madrid, España. leandro.prados.delaescosura@uc3m.es 


\begin{abstract}
Long run economic progress in modern Spain is assessed in this paper and its performance placed in European perspective. Over one and a half centuries, income per person rose 15 times. Three main phases can be established: 1850-1950, 1951-1974 and 1975-2000. Spain underperformed in the long run mostly due to its sluggish growth in specific phases of the century prior to 1950. Catching up took place in the late twentieth century, in which the years 1959-74 stand out. Structural change contributed significantly to growth acceleration while lack of exposition to international competition represents a recurrent element of retardation.
\end{abstract}

Keywords: Long-run growth, structural change, catching-up, Spain, Europe

JEL classification: N13, N14, N33, N34, O47, O52

\title{
INTRODUCTION
}

Accounts of economic performance in modern Spain tell a story of failure and retardation up to mid-twentieth century that led way to fast growth after 1960. The literature provides exogenous explanations in which inadequate natural resources, low human capital endowment, foreign «dependency», and inefficient institutions share the blame for the poor performance prior to mid-twentieth century but they fail to explain why the economic situation was reversed so dramatically thereafter ${ }^{1}$.

My goal in this paper is a more modest and preliminary one: I will try and assess long-run economic progress in modern Spain and place its performance during the Golden Age and its aftermath in historical perspective. In section I economic trends over the long run are described; the contribution of the demographic transition and structural change to growth is discussed in section II; section III offers an international perspective of Spain's performance. Section IV concludes.

\section{LONG-RUN PERFORMANCE: AN OVERVIEW}

Aggregate economic activity multiplied by 40 over one hundred and fifty years at trend growth rate of 2.4 percent per year. If we deduct a population increase of more than two and half times we find that, at the end of the twentieth century, per capita GDP was 15 times larger than at mid-nineteenth century (at a trend annual rate of 1.7 percent). Such a

\footnotetext{
${ }^{1}$ Cf. Tortella (1994b).
} 


\section{GRAPH 1}

REAL PER CAPITA GDP, 1850-2000

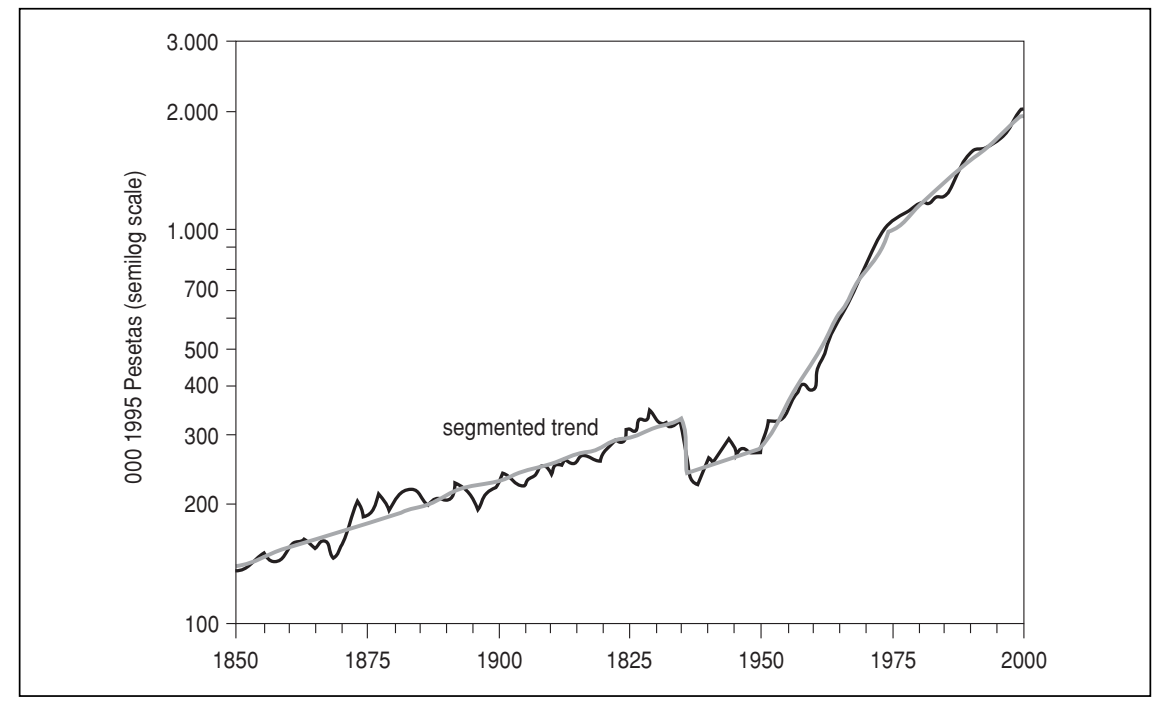

significant improvement did not take place at a steady rate. Spain's GDP series is trend stationary with structural breaks in level (1936) and in trend (1951 and 1975) (See Appendix) ${ }^{2}$. Three main phases: 1850-1950, 1951-1974 and 1975-2000, can be, then, established with a shift to a lower level during the first period resulting from the Civil War (1936$1939)^{3}$. In the Golden Age (1950-1974) GDP per capita rose seven times more rapidly than during the previous hundred years (1850-1950) and twice as fast as during the last quarter of the twentieth century. Thus the rate of growth experienced between 1850 and 1950 meant that product per person doubled every 99 years while the same increase was achieved every 13 years in 1951-1974 and every 27 years over 1975-2000 (Table 1).

2 A change of trend indicates a break in the long-term rate of growth while a change in level represents an increase or, as in the case of the Civil War years, a drop in economic activity which does not alter the established growth rate. It should be distinguished between the trend growth rate and the GDP level, the former being the relevant one to establish a periodisation. Thus, the relevant fact for accepting 1951 as structural break is that the trend growth rate change after this year and not that the GDP level was lower in 1951 than in 1929.

${ }^{3}$ If the slump caused by the Civil War were not taken into account the trend growth rate would reach 2.6 percent. The difference between these two figures, 0.2 percent, could be interpreted as the reduction in the long run annual growth rate caused by the civil conflict $(8 \%[=0.2 / 2.4])$. If we consider the effect on product per person, the corresponding figure is 0.25 percent annually which represents a drop of almost 15 percent. 
TABLE 1

PHASES OF GROWTH IN SPAIN, 1850-2000 (\%)

(Annual average logarithmic rates of change)

\begin{tabular}{|l|c|c|c|}
\hline & GDP & Population & $\begin{array}{c}\text { Per Capita } \\
\text { GDP }\end{array}$ \\
\hline $1850-2000$ & 2.4 & 0.6 & 1.8 \\
\hline $1850-1950$ & 1.3 & 0.6 & 0.7 \\
$1950-1974$ & 6.4 & 1.0 & 5.4 \\
$1974-2000$ & 3.0 & 0.4 & 2.6 \\
\hline $1850-1883$ & 1.8 & 0.4 & 1.4 \\
$1883-1920$ & 1.2 & 0.6 & 0.6 \\
$1920-1929$ & 3.5 & 1.0 & 2.6 \\
$1929-1952$ & 0.6 & 0.9 & -0.3 \\
$1952-1958$ & 4.4 & 0.8 & 3.5 \\
$1958-1974$ & 6.9 & 1.1 & 5.9 \\
$1974-1986$ & 2.5 & 0.7 & 1.8 \\
$1986-2000$ & 3.5 & 0.2 & 3.3 \\
\hline
\end{tabular}

Sources: Prados de la Escosura (2003).

The view of continuity in Spain's economic growth between 1850 and 1950 contrasts with the widely held interpretation of the nineteenth century as a period of economic failure and that of the twentieth century as one of success (Tortella 1994a), while confirms previous findings for the period 1850-1935 (Cubel and Palafox 1998, Carreras 1987, 1992). Phases or long swings in which growth rates differ from the long-run trend as a result of economic policies, access to international markets and technological change can be distinguished ${ }^{4}$.

During the first phase, 1850-1883, the rate of growth of product per person was well above the nineteenth century's average. It can be partly attributed to a 'reconstruction effect' after the political instability and social unrest of the early nineteenth century in which demographic expansion would have cancelled out most of the moderate growth in output $^{5}$. Institutional reforms and opening up to foreign capital and

4 The phases defined in the lower panel of Table 1 correspond with the time division arising from econometrically estimated deviations from the established trend (Prados de la Escosura 2003). Growth rates are measured as average annual logarithmic rates of change over periods delimited by peak years. These rates have a clearer meaning than trend growth rates based on statistical adjustment. In addition, they have additive properties.

5 The fact that per capita income improved little over 1815-1850 should not obscure the achievement of maintaining the standard of living despite the acceleration in population growth (Cf. Prados de la Escosura 1988 and Rosés 2003). Pérez Moreda (1999: 44) calculates a demographic growth of 0.76 percent between 1821 and 1860 compared with 0.42 percent for the eighteenth century. 
international trade lie beneath the significant growth experienced during the next three decades. Inflows of foreign capital made it possible to break the close connection between investment and savings and contributed to the economic growth (Prados de la Escosura 2007a).

A slowdown in growth took place between the mid 1880s and 1920 . This was a period of institutional stability that presumably provided a favourable environment for investment and growth yet both permanent and temporary factors worked against it.

Restrictions on both internal and external competition help to explain sluggish growth despite institutional stability during most of the Restauración (1875-1923) (Fraile Balbín 1998). Increasing tariff protection, together with exclusion from the prevailing international monetary system, the gold standard, represented a major obstacle to Spain's integration in the international economy ${ }^{6}$. The Cuban War of Independence, despite the already weakened economic links between the Spain and its colony, caused significant macroeconomic instability that brought forward the fall of the peseta and worsened Spain's international economic isolation ${ }^{7}$. Although the loss of Cuba had little direct economic impact, the protectionist and isolationist tendencies of the early twentieth century could have been its political consequence (Fraile Balbín and Escribano 1998). Macroeconomic instability reduced capital flows leading to the depreciation of the peseta - with a significant lag with respect to the cease of convertibility - that, in turn, increased the cost of emigrating and, hence reduced the outward flow of labour ${ }^{8}$. The move towards isolation can be seen in the evolution of relative factor prices. The land rent/wage ratio tended to fall between the early 1890s and the First World War (Prados de la Escosura 2006) while the opposite pattern is observed in open European countries (O'Rourke and Williamson 1999).

The pre-1914 years saw a brief period of increased activity coinciding with the peseta's recovery since $1905^{\circ}$. During World War I, instead, economic activity hardly progressed (below 0.6 percent annually) stagnating in per capita terms. This result is in stark contradiction with the conventional view that stresses its stimulating aggregate effects ${ }^{10}$.

${ }^{6}$ Cf. Tena (1999), Palafox (1999) and Pardos (1998) on tariff protection and its effects. See Martín Aceña (1994) and Bordo and Rockoff (1996) on the gold standard.

7 See the discussion in Fraile and Escribano (1998), Maluquer de Motes (1999) and Prados de la Escosura (2007a).

8 Cf. Martín Aceña (1999) and Prados de la Escosura (2007a) on mobility of capital and Sánchez Alonso (2000) on emigration.

9 Between 1905 and 1913 absolute GDP grew at a rate of 2.5 percent while GDP per capita did so by 1.8 percent.

${ }^{10}$ Cf. Roldán and García Delgado (1973) for the established view on the impact of the Great War on Spain. 
The most intense growth of the period 1850-1950 was achieved in the 1920s, and as it coincided with the Primo de Rivera Dictatorship (19231929) economists and historians have inevitably tended to make connections. Intervention in and regulation of economic activity increased during the Dictatorship (Comín 1987, Fraile 1998). The hypothesis that Government intervention in the form of protectionist measures and regulation and through investment in infrastructure were decisive factors behind this growth has been widely accepted (Velarde 1968). The emphasis on tariff protectionism tends to neglect, however, that Spain opened up to international factor flows during the 1920s. A significant inflow of foreign capital allowed the purchase of capital goods and raw materials which contributed to growth acceleration (Prados de la Escosura 2007a) ${ }^{11}$.

Lastly, a fourth long swing took place between 1929 and 1952. The effects of the Depression in aggregate terms were comparatively milder but more persistent ${ }^{12}$. The lively performance of the 1920 s, with rising GDP and private consumption per capita, does not support the old stereotype that deprivation and poverty, in a context of economic stagnation, led to the Civil War (1936-39). It could be argued that rapid growth led to a "war of attrition" over income distribution that intensified social and political tensions ${ }^{13}$. However, the fact that the Civil War (1936-39) happened after one and a half decades of inequality decline and poverty alleviation (Prados de la Escosura 2006) demands new explanatory hypotheses. Lagged perceptions of inequality and extreme poverty and unfulfilled expectations by those at the bottom of the distribution might lie at the roots of the civil conflict. Moreover, a process of polarization that triggered social and political conflict can be compatible with stable or declining inequality.

The weak recovery of the years from 1944 to 1952 stands out in the international context. In spite of World War II, European economies outperformed Spain (achieving an average growth rate of 1.4 compa-

11 It has also been noted that the positive situation of the current account balance of payments during the First World War contributed to the boom of the 1920s (Sudrià 1990).

12 In comparison with the nations which succeeded in abandoning the Gold Standard early (Eichengreen 1992), Spain did not experience a quick recovery. A restrictive public spending policy and the interruption of public projects in progress, together with political uncertainty has been pointed as the main causes of the 1930s crisis (Palafox 1991). Another view sustains, however, that expansionary monetary and anti-cyclical fiscal policies were tried to compensate for the fall in private investment and exports (Comín and Martín Aceña 1984, García Santos and Martín Aceña 1990).

13 There are historical examples of a link between relative deprivation and conflict following a period of economic expansion: France at the end of the $18^{\text {th }}$ century (Crouzet 1967), Russia in the early years of the $20^{\text {th }}$ century (Gregory 1994) and Mexico following the Porfiriato (Coatsworth 1990). 
red with Spain's 0.6) during the 1940s (Crafts and Mills 1996: 421). Spain's economy did not recover pre-war GDP levels (1929) until 1951 (in absolute terms), and 1955 (in per capita terms); in Europe, in contrast, it only took an average of 6 years to return to the pre-war level of income per capita and by 1953 all Western European countries had done so ${ }^{14}$. True that post-bellum Spain was surrounded by countries at war (Velarde 1993), but the fact that its economy only grew at a rate of 2.4 percent between 1944 and 1952 shows that only a slow recovery took place after a relatively mild contraction. Actually, at the trough during the Civil War (1938) Spain's GDP was equal to that of 1920 (and in per capita terms, to that of 1910), while the corresponding year during World War II for France's GDP was equivalent to that of 1891 and for Italy and Germany, to that of 1908 (Crafts and Toniolo 1996: 4).

The war destruction of physical capital was suffered mainly in housing, the transport network and livestock with the effect in industrial areas being limited. The destruction of physical capital can be estimated at around 8 per cent of the existing stock of capital in 1935, which would represent an average level of destruction in the context of World War II, although the concentration on productive capital (especially transport material) meant that levels of destruction caused by the conflict in Spain were far from negligible (Prados de la Escosura and Rosés 2007) ${ }^{15}$. Exile after the Civil War and, possibly to a larger extent, internal exile resulting from political repression of Franco's dictatorship, meant the loss of a considerable amount of Spain's limited human capital (Núñez 2003, Ortega and Silvestre 2006) ${ }^{16}$.

The change in trend which began in 1951 ushered in an exceptional phase of rapid growth which lasted until 1974. It is worth highlighting the fact that during the Golden Age (1950-1973), the main spurt of economic growth in Spain, as in other countries in the European Periphery, was delayed until the 1960s (Maddison 2001).

During the 1950s, industrialisation in Spain was largely dependent on internal demand. Import capacity's volatility rendered investment risky and tended to penalise capital accumulation, while inflows of foreign capital and new technology were restricted. In a way, Spain's case supports the counterfactual which maintains that without the Marshall Plan, Inter-war commodity and factor markets intervention, including quantitative restrictions on international trade and exchange controls

\footnotetext{
${ }^{14}$ According to Maddison (1996), Belgium, Holland and France did so in 1949, Italy in 1950 and Germany in 1953.

${ }^{15}$ Cf. Barciela (1986), Catalan (1995), Malefakis (1987) and Sánchez Asiaín (1999).

16 Regarding interior and exterior exile cf. López $(1991,1996)$ and Plá $(1994,1999)$.
} 
would have persisted as the main economic policies ${ }^{17}$. The move towards a pro-market attitude with deregulation and the gradual opening up of the economy which began with the 1959 reforms resulted in sustained growth and catching up with Western Europe during the late twentieth century.

\section{DEMOGRAPHIC TRANSITION, STRUCTURAL CHANGE, AND GROWTH}

In developing countries the transition to a modern demographic regime and the reallocation of resources from agriculture towards sectors with higher productivity plays a significant part in accelerating economic growth. How large was their contribution in the historical case of Spain?

During the demographic transition, the increase in the dependency ratio caused by the rise in fertility will tend to reduce the potential workforce compared within the total population ${ }^{18}$. Later, as those born during the demographic boom reach working age, the relative size of this potential workforce will increase before falling again as population ages. The potential effect of demographic change on per capita GDP is reflected in a time lag between the growth rate of the working-age population and that of the total population (Bloom and Williamson 1998) ${ }^{19}$. Their annual rates of change, once short-term fluctuations were eliminated with a Hodrick-Prescott filter (Graph 2) show that such a time lag is clearly visible, especially around the mid nineteenth century, in the second quarter of the twentieth century and, again, during its last 20 years. Graph 3 shows the relation between the size of the working-age population and the dependent population, with this ratio increasing in the periods 1860-80, 1920-50, and 1980-2000.

Another way to look at the contribution of the demographic transition to growth can be obtained by breaking down per capita GDP into its components using an identity in which Gross Domestic Product per person $(\mathrm{GDP} / \mathrm{N})$ equals product per occupied worker $(\mathrm{GDP} / \mathrm{L})$ times the rate of employment (L/EAP), times the activity rate (that is the ratio of the economically active population [EAP] to the population ages 15 to 64 or

\footnotetext{
17 The idea that the Marshall Plan's main contribution was to encourage a pro-market economic policy has been suggested by Eichengreen and Uzan (1992). Calvo (1999, 2001) has shown that in Spain there are similarities between the incentives for the market to operate as a mechanism of resource allocation provided by the USA-Spain agreements of 1953 and the Marshall Plan in Europe.

18 The dependency ratio is the proportion of the total population either under the age of 15 or over the age of 65 .

19 Cf. Williamson (1998), and Higgins and Williamson (1997).
} 


\section{GRAPH 2}

TOTAL POPULATION AND POTENTIALLY ACTIVE POPULATION (AGES 15-64): SMOOTHED RATES OF VARIATION

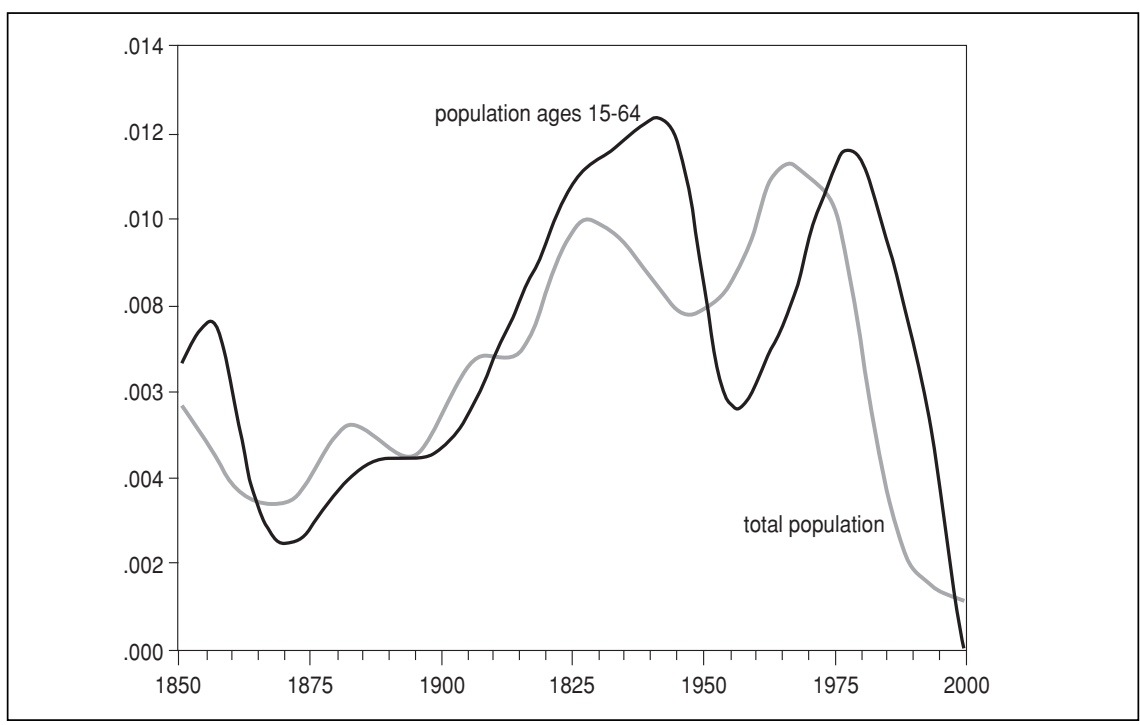

GRAPH 3

POTENTIALLY ACTIVE POPULATION TO DEPENDENT

POPULATION RATIO, 1850-2000

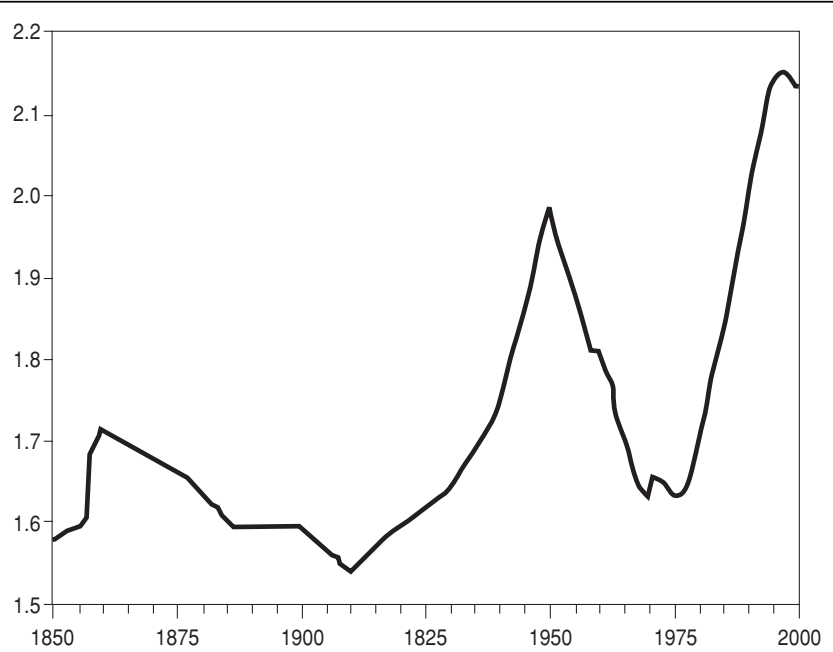


potentially active population, [PAP]) times the ratio between the potential labour force (PAP) and the total population $(\mathrm{N})$ :

$$
\text { (1) } \mathrm{GDP} / \mathrm{N}=(\mathrm{GDP} / \mathrm{L}) *(\mathrm{~L} / \mathrm{EAP}) *(\mathrm{EAP} / \mathrm{PAP}) *(\mathrm{PAP} / \mathrm{N})
$$

and in rates of change expressed in lower case letters,

$$
\text { (2) } \operatorname{gdp} / \mathrm{n}=(\operatorname{gdp} / \mathrm{l})+(\mathrm{l} / \mathrm{eap})+(\operatorname{eap} / \mathrm{pap})+(\mathrm{pap} / \mathrm{n})
$$

Table 2 shows the evolution of product per person and each of its components, expressed in logarithmic rates of growth, for the long swings identified over the last century and a half ${ }^{20}$. A demographic gift - a larger share of working age population-was responsible for a significant part of the per capita GDP growth during 1850-1866 and 19862000. The demographic bonus also played a part in mitigating the economic slowdown during the 1930s and 1940s and, again, during the transition to democracy (1978-86). On the contrary, in the Golden Age a negative demographic impact effected per capita income growth.

A rising rate of activity reinforced the demographic gift in 1855-74 and 1986-2000. The increase in the activity rate also played a beneficial role during the Golden Age and after Spain's admission into the European Community. Its fall proved, however, an obstacle to growth

TABLE 2

DECOMPOSING PER CAPITA GDP GROWTH. 1850-2000

\begin{tabular}{|l|c|c|c|c|c|}
\hline & $\begin{array}{c}\text { Per Capita } \\
\text { GDP }\end{array}$ & $\begin{array}{c}\text { GDP/ } \\
\text { employee }\end{array}$ & $\begin{array}{c}\text { Employment } \\
\text { /EAP }\end{array}$ & $\begin{array}{c}\text { EAP } \\
\text { /PAP }\end{array}$ & $\begin{array}{c}\text { PAP/ } \\
\text { Population }\end{array}$ \\
\hline $1850-2000$ & 1.8 & 1.7 & -0.1 & 0.1 & 0.1 \\
\hline $1850-1950$ & 0.7 & 0.7 & & 0.0 & 0.1 \\
$1950-1974$ & 5.4 & 5.3 & 0.0 & 0.4 & -0.3 \\
$1974-2000$ & 2.6 & 2.6 & -0.5 & 0.2 & 0.4 \\
\hline $1850-1883$ & 1.4 & 1.3 & & 0.1 & 0.0 \\
$1883-1920$ & 0.6 & 0.7 & & 0.0 & 0.0 \\
$1920-1929$ & 2.6 & 2.4 & & 0.0 & 0.1 \\
$1929-1952$ & -0.3 & -0.5 & & -0.1 & 0.3 \\
$1952-1958$ & 3.5 & 3.0 & 0.0 & 0.8 & -0.4 \\
$1958-1974$ & 5.9 & 6.0 & -0.1 & 0.2 & -0.3 \\
$1974-1986$ & 1.8 & 4.0 & -1.8 & -0.8 & 0.4 \\
$1986-2000$ & 3.3 & 1.4 & 0.6 & 1.0 & 0.3 \\
\hline
\end{tabular}

Sources: Prados de la Escosura (2003).

EAP: Economically Active Population; PAP: Potentially Active Population (15 to 64 years).

${ }^{20}$ The evidence to substantiate the assertions in this paragraph and the next one is provided in Prados de la Escosura (2003), pp. 165-170. 
during the Civil War and World War II, and again during the transition to democracy (1976-85) when it aggravated the negative impact of unemployment.

Labour productivity appears as the main determinant of per capita GDP growth and shadows it closely. Nonetheless, there are important exceptions: productivity overcame per capita GDP growth during 195974 and again the "transition to democracy» decade (1975-85). Conversely, from 1986 to 2000 productivity change lagged way behind per capita income growth. Employment creation (mostly in services) and productivity seem, thus, to exhibit an inverse relationship during the last quarter of the twentieth century.

The increase in aggregate productivity can be broken down into the part contributed by the increase in output per worker in each economic sector (internal productivity) and the part which is caused by the shift of labour from less productive to more productive sectors (structural change ${ }^{21}$. The level of aggregate labour productivity (A), which is obtained by dividing product $(\mathbf{O})$ by employment $(\mathbf{L})$ for the economy as a whole in the year $t$, can be expressed as the result obtained by adding the productivity $\left(\mathbf{O}_{\mathbf{i}} / \mathbf{L}_{\mathbf{i}}\right)$ for each economic sector $\mathbf{i}(\mathbf{i}=1,2, \ldots \mathrm{n})$, weighted according to each sector's contribution to total employment $\left(\mathbf{L}_{\mathbf{i}} / \mathbf{L}\right)^{22}$.

$$
\text { (3) } \mathrm{A}_{\mathrm{t}}=(\mathrm{O} / \mathrm{L})_{\mathrm{t}}=\Sigma\left(\mathrm{O}_{\mathrm{i}} / \mathrm{L}_{\mathrm{i}}\right)_{\mathrm{t}}\left(\mathrm{L}_{\mathrm{i}} / \mathrm{L}\right)_{\mathrm{t}}=\Sigma\left(\mathrm{A}_{\mathrm{it}} \mathrm{U}_{\mathrm{it}}\right)
$$

Where $\mathbf{A}_{\mathbf{i}}$ is product per worker in sector $\mathbf{i}$ and $\mathbf{U}_{\mathbf{i}}$ is the contribution of sector $\mathbf{i}$ to total employment.

From a temporal perspective, using lower case letters to represent rates of change,

$$
\text { (4) } \mathrm{a}_{\mathrm{t}}=\Sigma \mathrm{a}_{\mathrm{it}} \mathrm{U}_{\mathrm{it}}+\Sigma \mathrm{A}_{\mathrm{it}} \mathrm{u}_{\mathrm{it}}
$$

The method normally used for this calculation, shift-share analysis, involves estimating, in the first place, internal productivity growth (the first term on the right-hand side of equation (4)), that is the result obtai-

21 As correctly pointed out by Matthews, Feinstein and Odling-Smee (1982: 248-254), structural change is not really exogenous as it is caused by the interaction between the supply and demand of resources. In this sense the attempt to establish causal relationships between structural change and growth is flawed. From a historical point of view, however, perfect factor mobility does not exist and, consequently differences of marginal productivity between sectors tend to exist as the movement of resources from one sector to another does not take place automatically. For this reason improvements in resource allocation will contribute to growth during a given period of time. It is also the case that even when marginal productivity is the same in different industries, they will not all grow at the same rate. Growth will depend on their use of technological innovation and the existence of increasing returns.

22 I follow the procedure exposed by Broadberry (1998) in the subsequent paragraphs. 
ned by adding the growth of output per worker in each economic sector without varying the initial composition of employment. The difference between aggregate productivity and internal productivity will then provide the contribution of structural change.

This procedure is based on the assumption that, in the absence of labour shift between sectors, the level of productivity and the corresponding growth rate for each sector would have been identical to the actual ones. This assumption is not realistic in a case like Spain's in which if labour is quickly absorbed by industry and services, productivity tends to remain stable or to fall ${ }^{23}$. It would seem more reasonable to assume that agricultural productivity improved between 1950 and 1975 due to the reduction in the number of workers. It is also true that output per worker in industry between 1974 and 1986 would have grown more slowly if the number of workers had not fallen as a result of the industrial restructuring (reconversión) which eliminated less competitive branches reducing both the size of the sector and, consequently, industrial employment ${ }^{24}$. For this reason the contribution of structural change to the increase in productivity obtained using the conventional shiftshare analysis is presented as a lower bound in Table 3. An upper bound is obtained using a modified version of the conventional shift-share analysis which is obtained by subtracting from aggregate productivity the figure which would result by weighting product per worker growth in each sector according to its contribution to total employment in the initial year. An exception is made, however, for those sectors where contribution to employment falls (for example, agriculture over the whole period considered and industry since 1975); here the difference between the increase in aggregate employment and that of employment in that sector would be subtracted from output per worker growth ${ }^{25}$. The result obtained using this method has been called an upper bound because it does not take into account differences in levels of physical and human capital per worker across economic sectors ${ }^{26}$. As Table 3 shows, the differences between upper and lower bounds are considerable with the exception of the periods $1850-1883$ and 1929-52.

\footnotetext{
23 Broadberry (1998) puts forward the idea that if we accept, as proposed by Kindleberger (1967), that labour moving from agriculture to industry and services is surplus labour, then it must be assumed that the hypothetical return of this labour to the agricultural sector would have a negative effect on productivity.

24 This is suggested by the calculations of Suárez (1992) and van Ark (1995) regarding total factor productivity and labour productivity respectively.

25 This procedure is suggested by Broadberry (1998). In this case internal productivity would be calculated as $\Sigma \mathrm{a}^{\prime}{ }_{\mathrm{it}} \mathrm{U}_{\mathrm{it}}$, where $\mathrm{a}^{\prime}{ }_{\mathrm{it}}=\mathrm{a}_{\mathrm{it}}-\left(\mathrm{l}_{\mathrm{t}}-\mathrm{l}_{\mathrm{it}}\right)$, if $\mathrm{u}_{\mathrm{it}}<0$ (l representing employment)

26 Actually, the contribution of structural change should be calculated in terms of total factor productivity rather than in terms of labour productivity. The available evidence confirms, however, the importance of structural change: between 1965 and 1975, total factor
} 
TABLE 3

STRUCTURAL CHANGE AND LABOUR PRODUCTIVITY GROWTH. 1850-2000

\begin{tabular}{|l|c|c|c|c|c|}
\hline & GDP/EAP & $\begin{array}{c}\text { Internal } \\
\text { Productivity } \\
\text { (shift-share) }\end{array}$ & $\begin{array}{c}\text { Structural } \\
\text { Change } \\
\text { (lower bound) }\end{array}$ & $\begin{array}{c}\text { Internal } \\
\text { Productivity } \\
\text { (revised) }\end{array}$ & $\begin{array}{c}\text { Structural } \\
\text { Change } \\
\text { (upper bound) }\end{array}$ \\
\hline $1850-2000$ & 1.7 & 1.6 & 0.1 & 1.1 & 0.7 \\
\hline $1850-1950$ & 0.7 & 0.4 & 0.2 & 0.3 & 0.4 \\
$1950-1974$ & 5.3 & 4.9 & 0.4 & 3.4 & 1.9 \\
$1974-2000$ & 2.6 & 3.0 & -0.4 & 1.9 & 0.7 \\
\hline $1850-1883$ & 1.3 & 1.1 & 0.2 & 1.1 & 0.2 \\
$1883-1920$ & 0.7 & 0.6 & 0.1 & 0.4 & 0.3 \\
$1920-1929$ & 2.4 & 2.1 & 0.4 & 1.1 & 1.3 \\
$1929-1952$ & -0.5 & -0.5 & 0.0 & -0.5 & 0.0 \\
$1952-1958$ & 3.0 & 2.3 & 0.7 & 1.3 & 1.7 \\
$1958-1974$ & 6.0 & 5.4 & 0.6 & 3.8 & 2.2 \\
$1974-1986$ & 4.0 & 3.9 & 0.1 & 3.0 & 0.9 \\
$1986-2000$ & 1.4 & 1.7 & -0.3 & 0.9 & 0.5 \\
\hline
\end{tabular}

Sources: Prados de la Escosura (2003).

According to the upper bound estimate, structural change would account for two-fifths of the aggregate productivity growth achieved over the last 150 years. This figure is in line with Broadberry's findings (1998) for Germany and the United States between 1870 and $1990^{27}$. A closer look shows that between 1883 and 1929 structural change accounts for half of the increase in labour productivity and this figure rises to almost three quarters between 1873 and 1913. If we now focus on shorter cycles it can be shown that during periods of deceleration of growth such as 1883-1913, without a shift of agricultural labour towards industry and services, aggregate labour productivity would have grown by just 0.2 percent whilst the fall in level would have been even sharper in the early 1930s and the postwar recovery (1945-52) would have been even weaker. During the «Golden Age» one third of aggregate labour productivity was due to structural change, while in the 1950 s this proportion represented more than a half ${ }^{28}$. Over the last quarter of the twentieth century structural change has, once

productivity increased by 6.5 percent in industry compared with 2 percent in agriculture and 3.8 percent in aggregate terms (San Juan (1987); Gandoy (1988); Myro (1983); Súarez (1992)). See also the recent research by Sanchis (2001) for 1958-75.

27 Broadberry (1998: 390) estimates that for the increases in productivity of 1.75 percent and 1.43 percent in Germany and the USA, structural change would account for a maximum of 45.7 percent and 50.3 percent respectively.

28 The contribution of structural change is, it can be seen, far greater than the figure obtained by van Ark (1996: 96), using the conventional shift-share analysis method (with 22 percent as the upper limit). 
more, accounted for one-fourth of the increase in aggregate labour productivity. In this phase, the slow transfer of labour away from agriculture (which still employed one in four workers in 1975) was accompanied by the destruction of employment in less competitive manufacturing industries, a situation which has led to more than a 50 percent increase in employment in the service sector. Much of the explanation for the rapid rise in labour productivity in agriculture since 1975 is to be found in this shift of labour ${ }^{29}$. Structural change would also play a significant part in the increase in industrial productivity between 1974 and $1986^{30}$.

\section{SPAIN'S POSITION IN THE INTERNATIONAL ECONOMIC CONTEXT}

Spain's long term growth appears similar to that of western nations (Table 4). At first glance, such a finding would lend support to the view that the roots of most of today's difference in living standards between Spain and other advanced countries should be searched for in the pre1850 era. Things are more complex, however ${ }^{31}$. A closer look shows that long-run growth before 1950 was clearly lower than in the advanced countries, while the opposite was true for the second half of the twentieth century (Table 4, Panel A). Thus, Spain fell behind between 1850 and 1950. The second half of the nineteenth century witnessed sustained per capita GDP growth while paradoxically the gap with the industrialised countries widened over 1883-1913. Moreover, Spain did not catch up during the first half of the twentieth century. The progress made in the 1920s and the relatively mild impact of the 1930s crisis were more than outweighed by Spain's exclusion from the late 1930s recovery as a result of the Civil War. In the 1940s, despite being non-belligerant in World War II, she grew more slowly than the warring Western European nations. In the second half of the twentieth century, especially during the Golden Age. Spain outperformed the advanced nations improving her relative international position.

Nonetheless, to be properly assessed growth rates need to be related to the initial level of per capita GDP. Table 5 shows that at the begin-

29 In the modified shift-share analysis method used here 4.7 percent (that is the difference between the growth of total employment and that of agricultural employment) of the 6.2 percent increase in agricultural labour productivity can be attributed to structural change.

${ }^{30}$ As explained in the case of agriculture in the previous note, using this calculation method, 2.2 percent of the 5 percent annual growth in industrial labour productivity would be caused by structural change (that is the difference between the growth rate for total employment and that for industrial employment). Between 1986 and 1992, this would represent 1.5 percent of a total of 2.7 percent.

31 A new assessment of pre-1850 Spain is provided by Álvarez-Nogal and Prados de la Escosura (2007). 
TABLE 4

PER CAPITA GDP GROWTH IN SPAIN: AN INTERNATIONAL COMPARISON

\begin{tabular}{|l|c|c|c|c|c|}
\hline & Spain & $\begin{array}{c}\text { Advanced } \\
\text { Europe }\end{array}$ & $\begin{array}{c}\text { Continental } \\
\text { Europe }\end{array}$ & U.K. & U.S.A. \\
\hline $1850-1998$ & 1.8 & 1.7 & 1.7 & 1.4 & 1.8 \\
\hline $1850-1950$ & 0.7 & 1.2 & 1.2 & 1.1 & 1.7 \\
$1950-1998$ & 4.0 & 2.7 & 2.8 & 2.1 & 2.2 \\
$1850-1913$ & 1.0 & 1.3 & 1.3 & 1.2 & 1.7 \\
\hline $1913-1950$ & 0.2 & 1.2 & 1.3 & 0.9 & 1.6 \\
$1950-1974$ & 5.4 & 3.6 & 3.7 & 2.3 & 2.3 \\
$1974-1998$ & 2.5 & 1.8 & 1.8 & 1.9 & 2.1 \\
$1850-1883$ & 1.4 & 1.2 & 1.2 & 1.4 & 1.8 \\
\hline $1883-1913$ & 0.6 & 1.4 & 1.4 & 1.0 & 1.6 \\
$1913-1920$ & 0.8 & -1.0 & -1.0 & -1.1 & 0.7 \\
$1920-1929$ & 2.6 & 3.3 & 3.5 & 1.4 & 2.4 \\
$1929-1952$ & -0.3 & 0.9 & 0.9 & 0.9 & 1.3 \\
$1952-1958$ & 3.5 & 3.5 & 3.6 & 2.0 & 0.5 \\
$1958-1974$ & 5.9 & 3.7 & 3.9 & 2.5 & 2.7 \\
$1974-1986$ & 1.8 & 1.9 & 1.9 & 1.8 & 2.1 \\
$1986-1998$ & 3.3 & 0.8 & 0.8 & 0.7 & 0.8 \\
\hline
\end{tabular}

Sources: Maddison (2001, 2003), except for Spain, Prados de la Escosura (2003).

* Advanced Europe (population weighted average): Germany, Austria, Belgium, Denmark,

France, the Netherlands, U.K., Sweden, Italy, Finland, Norway, and Switzerland.

Continental Europe (unweighted): Advanced Europe, excluding the U.K.

ning of the Golden Age Spain's income per head was way below that of industrial nations. Thus, within a neoclassical growth framework although Spain reached western European pace of growth in the 1950s, a faster one could have been expected from her lower initial per capita income.

On the whole, Spain's relative position at the end of the twentieth century was worse than it had been in 1850 and hardly improved since the late nineteenth century. In the long run Spain exhibits a tendency to return to a stable position at around three quarters of Western European per capita income (and half that of the USA). In fact, after her relative position collapsing during the first two decades of Franco's dictatorship (1939-59) accelerated growth over 1960-75 allowed Spain to recover the international position she attained at the beginning of the twentieth century. After a worsening during the decade of "transition to democracy», a lively recovery led to much the same position in the late 1990s as at the time of Franco's death (1975). Does this mean that Spain's steady state is lower than that the advanced European nations? ${ }^{32}$.

32 Since 2000 Spain has improved her position up to the relative level achieved by 1929. 
TABLE 5

SPAIN'S RELATIVE LEVELS OF PER CAPITA GDP (\%)

(US Current Relative Prices)

\begin{tabular}{|l|c|c|c|c|}
\hline & \multicolumn{2}{|c|}{ Advanced Europe* $^{*}$} & Western Europe ** & \multirow{2}{*}{ U.S.A. } \\
\cline { 2 - 4 } & 8 countries & 12 countries & 14 countries & \\
\hline 1850 & 91.0 & & & 64.2 \\
1860 & 90.5 & & & 64.8 \\
1870 & 75.8 & & & 56.0 \\
1880 & 83.3 & 88.9 & 93.8 & 56.8 \\
1890 & 79.4 & 85.1 & 89.9 & 56.8 \\
1900 & 73.1 & 77.2 & 82.8 & 52.5 \\
1913 & 72.3 & 75.9 & 80.8 & 51.1 \\
\hline 1925 & 76.7 & 79.1 & 84.5 & 46.0 \\
1929 & 75.1 & 77.6 & 82.9 & 46.2 \\
1933 & 66.3 & 68.5 & 73.7 & 50.4 \\
1938 & 46.4 & 47.8 & 51.3 & 33.8 \\
\hline 1950 & 66.0 & 66.0 & 70.2 & 35.2 \\
1955 & 64.9 & 64.8 & 69.0 & 36.4 \\
1960 & 52.9 & 53.7 & 57.3 & 33.1 \\
1965 & 60.9 & 61.7 & 65.8 & 42.1 \\
1970 & 60.5 & 61.8 & 65.8 & 43.3 \\
1975 & 71.1 & 72.0 & 76.7 & 57.3 \\
1980 & 68.7 & 67.4 & 72.2 & 55.9 \\
1985 & 68.6 & 67.6 & 72.1 & 48.1 \\
1990 & 70.3 & 70.1 & 74.0 & 56.5 \\
1996 & 71.7 & 70.3 & 76.4 & 54.7 \\
1999 & 73.7 & 72.5 & & 54.7 \\
\hline
\end{tabular}

Sources: Prados de la Escosura (2000). 1850-1990; OECD (1999). 1996, 1999.

* Advanced Europe: 8 countries: Germany, Austria, Belgium, Denmark, France, the Netherlands,

U.K., and Sweden, 12 countries: 8 countries plus, Italy, Finland, Norway, and Switzerland.

** Western Europe: 14 countries: 12 Advanced Europe's countries plus Greece and Portugal.

What did determine Spain's position relative to western European economies? In an attempt to provide an answer I have estimated a growth model for modern Europe in which per capita GDP growth is associated to the initial levels of (log of) per capita income and primary and secondary school enrolment (as proxies for initial physical and human capital endowment), the average investment ratio to GDP and the growth of population (as proxies for changes in the stock of physical capital and labour), resource allocation indicators (that include the shift of resources away from agriculture, proxied by the initial share of active population in agriculture and by the (log of) average ratio of agricultural to industrial output), and the change in openness (as measured by the rate of variation of the export share in GDP) (Prados de la Escosura 2007b). A time trend dummy was added to capture temporal changes in 
the dependent variable not associated with variations in the independent variables (and to eliminate all variation between periods that makes the result correspond to that of a weighted cross section).

Additionally, I allowed for a boost to growth from post-war episodes of reconstruction (in the 1920s and 1950s) in an attempt to clarify the part of growth not easily explained by the conventional variables of the (basic and augmented) neo-classical model. The post-war to pre-war ratio of physical capital per person, and changes in the human to physical capital endowment ratio have been used in historical studies of European reconstruction (Crafts 1992, Dumke 1990). In the former case I approximated it with the post-war to pre-war income per head ratio (1920/1913 and 1950/1938) and its quadratic term to incorporate its diminishing impact on growth. For the latter, as no data on human and physical capital stocks were available for all countries in the sample I used schooling and investment flows as proxies. Lagged values of the independent variables have been used as instruments to take endogeneity into account. The regression results (Table 6) shows a good fit with only over one-forth of the variance unexplained. A strong conditional convergence effect appears to exist as measured by the negative and high coefficient of the initial level of income (and shown by the speed of convergence), and the remaining coefficients present the expected relations, positive for accumulation and openness, and negative for tying resources to agriculture.

Per capita GDP growth for Spain can be predicted using equations alternatively representing the unconditional convergence, the basic and augmented (with human capital) Solow, and structural models, the latter incorporating resource allocation, openness, and a «reconstruction» effect (in the two alternative specifications described above) (Table 7). This way the intuitive interpretation of Spain's historical performance presented earlier in this paper can be tested.

The predicted rate of per capita GDP growth for Spain represents the «potential» growth within a European historical context under a common set of restrictions. The comparison of the different predictions for Spain resulting from alternative growth models deserves a few remarks. In the first place, with the exception of the Golden Age, the unconditional convergence forecasts a faster per capita growth (col. I) than the Solow model one (col. II), a finding that suggests that the rate of capital accumulation was lower in Spain than in the European case. Prior to 1920, weaker human capital accumulation also contributes to explain the systematically lower growth forecasted by the augmented Solow model (col. III) relative to the unconditional convergence one. The potential for growth that results from structural change is highlighted by the fact that the predictions of the models including resource allocation, 
TABLE 6

DETERMINANTS OF GROWTH IN EUROPE, 1820-1990

(TSLS pool regression)

\begin{tabular}{|c|c|c|c|c|c|}
\hline & (1) & (2) & (3) & (4) & (5) \\
\hline Constant & 0.0811 & 0.1030 & 0.1064 & 0.2630 & 0.2292 \\
\hline & $(5.490)$ & $(6.296)$ & $(6.156)$ & $(6.966)$ & $(5.141)$ \\
\hline LY90 & -0.0119 & -0.0157 & -0.0171 & -0.0353 & -0.0307 \\
\hline & $(-5.392)$ & $(-6.597)$ & $(-6.264)$ & $(-7.694)$ & $(-5.594)$ \\
\hline SINVT & & 0.1158 & 0.1089 & 0.1074 & 0.1151 \\
\hline & & $(5.025)$ & $(4.233)$ & $(4.428)$ & $(4.856)$ \\
\hline GPOP1 & & 0.1252 & 0.1685 & 0.1330 & 0.0133 \\
\hline & & $(0.548)$ & $(0.365)$ & $(0.516)$ & $(0.042)$ \\
\hline ESCOLAR & & & 0.0038 & -0.0036 & -0.0021 \\
\hline & & & $(0.365)$ & $(-0.387)$ & $(-0.215)$ \\
\hline AGLAB & & & & $\begin{array}{l}-0.0263 \\
(-1.605)\end{array}$ & $\begin{array}{l}-0.0228 \\
(-1.369)\end{array}$ \\
\hline LSPOI & & & & -0.0075 & -0.0068 \\
\hline & & & & $(-2.825)$ & $(-2.573)$ \\
\hline GXB & & & & $\begin{array}{r}0.0786 \\
(2.241)\end{array}$ & $\begin{array}{r}0.1067 \\
(2.814)\end{array}$ \\
\hline TBIAS & 0.0003 & 0.0002 & 0.0003 & 0.0003 & 0.0002 \\
\hline RCNSTRC & $(8.944)$ & (5.135) & $(4.831)$ & $\begin{array}{r}(4.982) \\
0.0141\end{array}$ & (3.241) \\
\hline KCNSTKC & & & & $\begin{array}{l}-0.0141 \\
(-1.467)\end{array}$ & \\
\hline RCNSTRC2 & & & & $\begin{array}{l}0.1018 \\
(2364)\end{array}$ & \\
\hline HPK & & & & & 0.0053 \\
\hline & & & & & (2.330) \\
\hline $\begin{array}{l}\mathbf{N}^{\mathbf{o}} \text { Obs. } \\
\overline{\mathbf{R}}^{2}\end{array}$ & $\begin{array}{r}163 \\
0.364\end{array}$ & $\begin{array}{r}127 \\
0.516\end{array}$ & $\begin{array}{r}108 \\
0.525\end{array}$ & $\begin{array}{r}89 \\
0.722\end{array}$ & $\begin{array}{r}85 \\
0.689\end{array}$ \\
\hline $\begin{array}{l}\mathbf{R}^{2} \\
\text { S.E.Regression }\end{array}$ & 0.012 & 0.010 & 0.010 & 0.008 & $\begin{array}{l}0.009 \\
0.008\end{array}$ \\
\hline F-Statistic & 47.455 & 34.628 & 24.615 & 23.874 & 21.688 \\
\hline Speed of & & & & & \\
\hline Convergence & 0.0127 & 0.0170 & 0.0187 & 0.0435 & 0.0359 \\
\hline
\end{tabular}

Instruments: Lagged and initial values of regressors. (t statistics in brackets). Dependent Variable: Per Capita GDP growth rate (\%) Constant: Constant term. LY90: Log of real per capita GDP at the beginning of each period, in 1990 US \$, PPP. SINVT: Ratio of gross domestic investment to GDP, calculated as ten-year averages. GPOP1: Rate of population of growth. ESCOLAR: Primary and secondary school enrolment as a ratio to population aged 5 to 19 at the beginning of each period. AGLAB: Labour force in agriculture as a ratio to total labour force at the beginning of each period. LSPOI: Index of production orientation (Log of Agricultural-Industrial output ratio), calculated as ten-year averages. GXB: Growth rate of exports ratio to GDP. TBIAS: Time trend. RCNSTRC: Dummy of reconstruction processes. For 1950-1960, it is the log of 1950/1938 per capita income ratio; for 1920-1929, the log of 1920/1913 per capita income ratio; otherwise, takes zero value. RCNSTRC2: Square of RCNSTRC. HPK: Human Capital to Physical Capital Ratio, proxied by the Post-World War ESCOLAR/SINVT to the to Pre-World War ESCOLAR/SINVT ratio. For 1950-1960, it is the 1950/1938 ratio; for 1920, the 1920/1913 ratio; otherwise takes zero value

Source: Prados de la Escosura (2007b) 
TABLE 7

PER CAPITA GDP GROWTH IN SPAIN: PREDICTED AND ACTUAL RATES (\%)

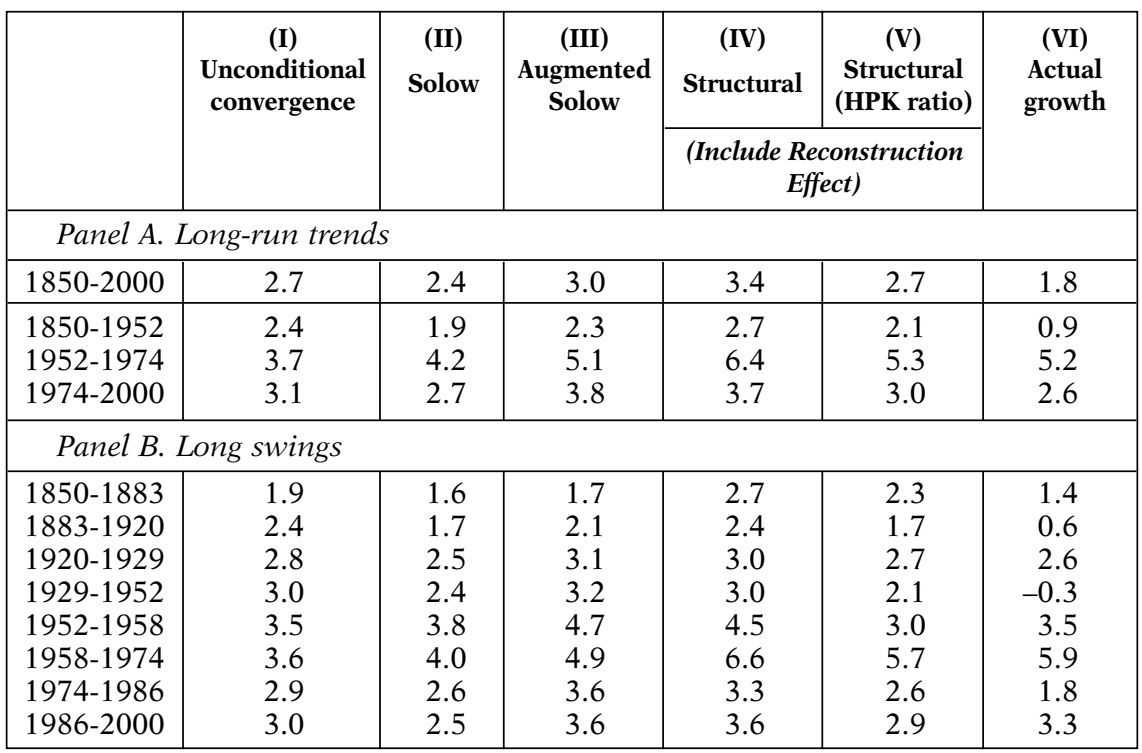

Sources: Columns I-V computed with equations 1-5 from Table 6. Column VI, from Table 1.

openness, and a «reconstruction» effect are systematically above those of the unconditional convergence model for periods of accelerating growth such as $1850-83$ and $1958-74^{33}$. In fact, the growth differential in the predictions of the two structural models (cols. IV and V) is very revealing, with a lower growth rate cast by the structural model that uses the human capital to physical capital ratio as a proxy for the «reconstruction» effect (col. V). Human capital endowment appears to be the key and model V provides the best prediction of Spain's economic performance in the second half of the twentieth century. In Spain, (as opposed to German or Japanese experiences), the destruction of human capital was higher than that of physical capital during the Spanish Civil War and its repressive aftermath (the exile and, especially, the internal exile), and this fact helps explain the weaker performance of Spain's economy during the 1940s and the early Golden Age.

When the models' predicted growth are confronted with the actual rates, it clearly appears that Spain underperformed over the long run

${ }^{33}$ And, if the structural model presented in equation (4) (col. IV of Table 7) is employed, also for the 1920s, the 1950s, and 1974-2000. 
mostly due to its sluggish growth in the hundred years up to 1950, more specifically in the periods 1883-1913 and 1929-1952. The Golden Age, especially, the period 1958-74, and the last one and a half decades of the twentieth century stand out as years of outstanding performance (with the 1920s just below it!). A closer look singles out 1866-73, 1964-74, and 1986-92 as cycles of overachievement. The Restauración (namely 18751923 but arbitrarily restricted here to 1883-1920), the 1930s and 1940s, and the transition to democracy after Franco's death (1975-85) stand out, in turn, as those phases responsible for Spain's poorer economic performance relative to western Europe ${ }^{34}$.

How much did structural change contribute to the model's predicted growth can be established, for example, by simulating ceteris paribus the impact of maintaining fixed either the sectoral resource allocation, the change in openness, or the rate of capital accumulation of, say, the previous period, on the rate of forecasted growth. Thus, it appears that without the moderate shift of resources away from agriculture that took place in the Restauración growth would have been slightly over threefourths of the model's predicted rate. In the decade of «transition to democracy» (1976-85) it would have represented two-thirds of the forecasted growth (when the shift away from agriculture and non competitive industry is taken into account). Capital accumulation, in turn, mattered especially during the 1920s and 1950s and the counterfactual growth that would have been achieved with the investment rate of the previous period represents three-fourths and two-thirds, respectively, of the predicted per capita GDP growth. Finally, the increasing openness represented that, in 1958-74, the model's predicted growth practically doubled the counterfactual rate obtained by keeping constant the pace of openness that prevailed in the 1950s.

The change in the rate of forecasted growth between successive long swings can be decomposed, using equation (5) of Table 6, into the contributions of a catching-up effect (which includes the initial values of income and schooling, and the impact of 'reconstruction'), and those resulting from capital accumulation, population growth, sectoral resource allocation, and changes in the degree of openness (Table 8).

It appears that the deceleration during the Restauración (reduced to 1883-1920 here) resulted from a weakening of the catching-up effect and the closing of the economy that tended to offset the timid shift of resources away from agriculture. In the 1920s the increase in capital accumulation seems to have been the main element behind growth acceleration and, once again, the mild reallocation of resources was cancelled out by

34 The evidence to substantiate the assertions in this paragraph and the last one comes from Prados de la Escosura (2003), pp. 168-182. 


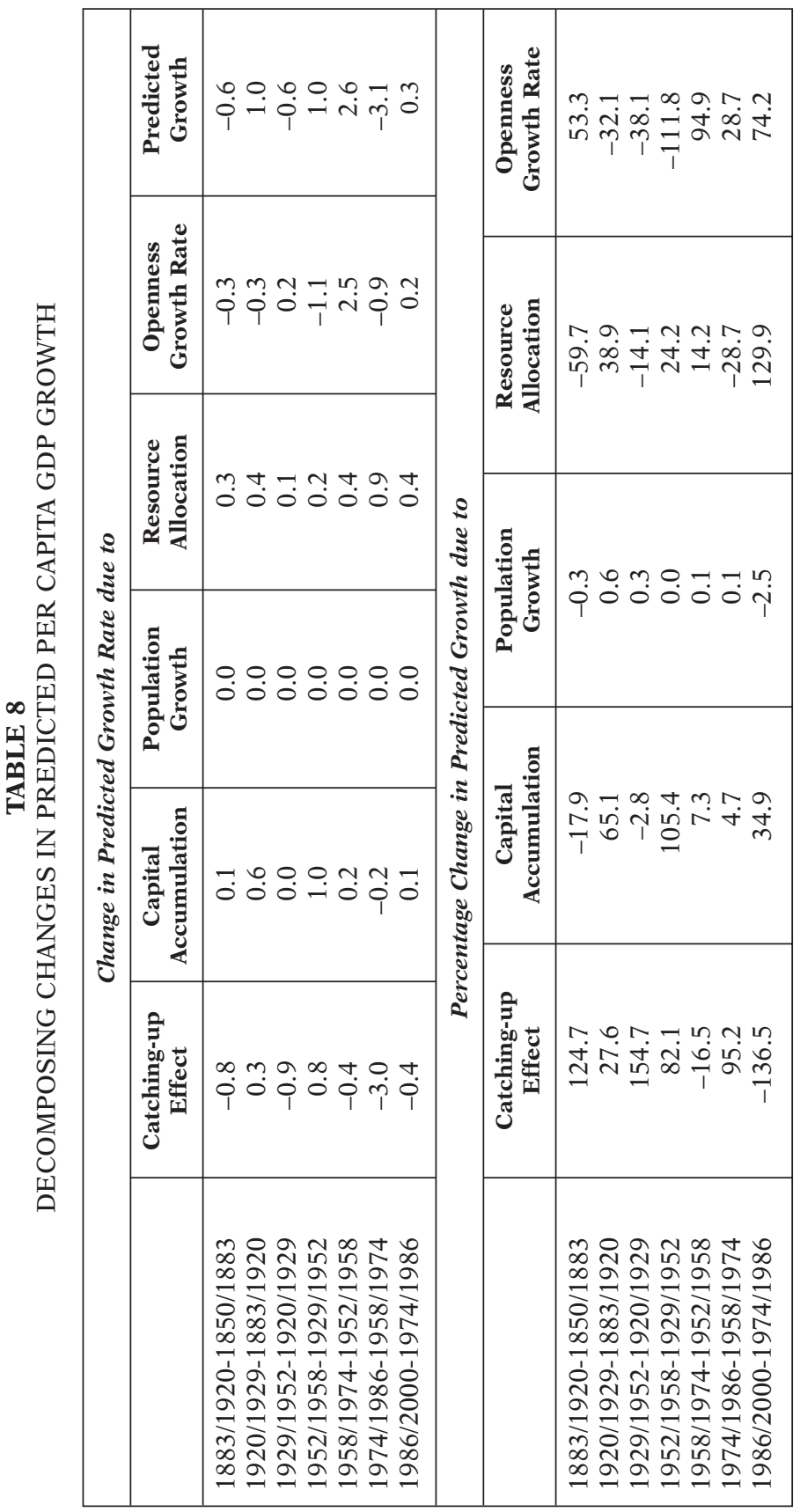


the lower exposition to international competition. During the 1950s, in turn, growth acceleration appears associated to increasing investment and to catching up after the isolation of the previous decades. Nonetheless, lack of openness, is suggested, still represented a brake on growth. It was during the decade and a half of accelerated growth that followed the Stabilization Plan (1958-74) when increasing openness was its main contributor. Spain's poor adjustment to international competition following the oil crises of the 1970s evidenced the delayed negative consequences of Francoist interventionism and protectionism. Shifts of resources away from agriculture and non competitive industry (that had grown under the protectionist umbrella) mitigated the slowdown of the decade of transition to democracy (to which the lack of openness contributed) and stimulated growth after Spain's admission in the European Community, to which increasing openness and capital accumulation also contributed. In any case, the results in Tables 7 and 8 provide more questions than answers and constitute an agenda for further research.

\section{CONCLUDING REMARKS}

Over one and a half centuries, the level of economic activity increased forty times while income per person rose to 15 times its initial level. The distinction of three main phases: 1850-1950, 1951-1974 and 19752000 confirms the continuity of growth between 1850 and 1950, in contrast with the widespread view of a nineteenth century characterised by failure and a twentieth century of economic success.

Per capita GDP growth cannot be attributed exclusively to the Golden Age as there is evidence of significant growth during 1850-1883 and in the 1920s. Alternatively, 1883-1920, 1929-1952 and 1974-1986 represent phases of sluggish growth.

Spain underperformed over the long run mostly due to its sluggish growth in specific periods $(1884-1913,1930-52)$ of the hundred years up to 1950 . Higher destruction of human capital than of physical capital during the Spanish Civil War and its aftermath help explain her performance during the 1940s and 1950s. Spain's economy has been catching up with advanced countries over the last fifty years in which 1959-74 stand out as a period of outstanding performance and the transition to democracy (1975-85) as the exception. Structural change appears to have contributed significantly to growth acceleration while lack of exposition to international competition represents a recurrent element of retardation. 


\section{APPENDIX}

\section{Statistical characteristics of the new GDP series}

Whether a series is deterministic (trend stationary [TS]) or stochastic (difference stationary [DS]) which then requires transformation to become stationary, has important economic implications. While in the case of a trend stationary series an external shock will not affect its long run performance, merely setting in motion a cyclical episode before returning to the established trend, in the difference stationary case shocks lead to permanent consequences. That is, the past has a stronger influence on the present when the series are non stationary. From the point of view of growth theory such a distinction means that while the trend stationary GDP follows the neo-classical model, the difference stationary trend is closer to endogenous growth models (Crafts and Mills 1996, Ben-David, Lumsdaine and Papell 1996).

Nevertheless, faced with a long macroeconomic series which has a unit root i.e. a series which in principle is not stationary, the possibility that it may, actually, be a stationary series with one or several permanent changes of level or trend (Perron 1989, Campbell and Perron 1991) exists. This possibility is clearly closer to the idea of growth held by economic historians ${ }^{35}$.

The first results of the conventional unit root tests indicate that GDP, in levels, displays non-stationary characteristics. The results of the augmented Dickey-Fuller test confirm that both the absolute and the per capita GDP series are DS (Table A.1), that is to say only the first differences are stationary. The GDP series would contain a unit root. This

TABLE A.1

UNIT ROOT TESTS

\begin{tabular}{|l|l|r|}
\hline & Ln(Yt-1) & \multicolumn{1}{|c|}{ D(Yt-1) } \\
\hline GDP & $-0.64(1)$ & $-9.99(1)$ \\
Per Capita GDP & $-0.46(1)$ & $-10.05(1)$ \\
\hline
\end{tabular}

Note: Values for the $\mathrm{t}$ statistc that belongs to the coefficient of the lagged variable $\mathrm{Yt}-1$ derived with the augmented Dickey-Fuller test $\Delta \mathrm{Y}_{\mathrm{t}}=\mu+\beta \mathrm{t}+\gamma \mathrm{Y}_{\mathrm{t}-1}+\sum \delta_{\mathrm{i}} \Delta \mathrm{Y}_{\mathrm{t}-\mathrm{j}+1}+\varepsilon_{\mathrm{t}}$

Figures in brackets correspond to the number of lags in the dependent variable required to eliminate autocorrelation. Critical significant values at 1,5 y 10 percent are, respectively, $-4,02,-3,44$ and $-3,14$.

35 Crafts and Mills (1996) add that, from a European perspective, discontinuities in the historical GDP series are highlighted. 
indicates that the mean of the series varies depending on the period considered. Nevertheless, whether we are, in fact, dealing with stationary series which suffer changes of level or trend in the long term needs to be investigated. In order to check for structural changes it is necessary to establish the moment such a change would be expected. Once again, there are two alternative options: to assign a specific date for the structural change hypothesis or allow the structural break to be decided endogenously using recursive, sequential or other procedures. While econometricians and time series analysts usually prefer the second approach, historians tend to plump for the first ${ }^{36}$. The reason for this preference for a formally imperfect system is to be found in the fact that time series analysis provides a powerful tool which allows us to test historical hypotheses related to the existence of phases of growth ${ }^{37}$.

In order to confirm the existence of a segmented series the model which appears in Table A.2 has been tested, that includes dummy varia-

TABLE A.2

UNIT ROOT TESTS INCLUDING EXOGENOUS STRUCTURAL BREAKS (dependent variable: $\Delta \mathrm{Y}_{\mathrm{t}}$ )

\begin{tabular}{|l|r|r|r|r|}
\hline \multirow{2}{*}{ variable } & \multicolumn{2}{|c|}{ GDP } & \multicolumn{2}{c|}{ Per Capita GDP } \\
\cline { 2 - 5 } & coefficient & t statistic & coefficient & t statistic \\
\hline constant & -7.7362 & $(-4.08)^{\mathrm{b}}$ & -5.6285 & $(-4.29)^{\mathrm{a}}$ \\
time & 0.0057 & $(4.11)^{\mathrm{b}}$ & 0.0042 & $(4.37)^{\mathrm{a}}$ \\
$\ln \mathrm{Y}_{\mathrm{t}-1}$ & -0.3628 & $(-4.12)^{\mathrm{c}}$ & -0.4175 & $(-4.49)^{\mathrm{b}}$ \\
$\Delta \mathrm{Y}_{\mathrm{t}-1}$ & 0.2205 & $(2.99)^{\mathrm{a}}$ & 0.2320 & $(3.30)^{\mathrm{a}}$ \\
$\mathrm{DU}_{1935}$ & -0.0867 & $(-2.82)^{\mathrm{b}}$ & -0.1323 & $(-3.54)^{\mathrm{a}}$ \\
$\mathrm{DT}_{950}$ & 0.0181 & $(4.10)^{\mathrm{b}}$ & 0.0182 & $(4.49)^{\mathrm{a}}$ \\
$\mathrm{DT}_{1974}$ & -0.0131 & $(-4.35)^{\mathrm{a}}$ & -0.0116 & $(-4.59)^{\mathrm{a}}$ \\
\hline $\mathrm{R}^{2}$ ajusted & 0.34 & & 0.37 & \\
Durbin-Watson & 1.87 & & 1.83 & \\
F statistic & 13.55 & & 15.49 & \\
\hline
\end{tabular}

Notes: The Augmented Dickey-Fuller that incorporates structural breaks implies a regression as $\Delta \mathrm{Y}_{\mathrm{t}}=\mu+\beta \mathrm{t}+\alpha \mathrm{Y}_{\mathrm{t}-1}+\sum \mathrm{c}_{\mathrm{j}} \Delta \mathrm{Y}_{\mathrm{t}-\mathrm{j}}+\theta \mathrm{DUi} \mathrm{i}_{\mathrm{t}}+\gamma \mathrm{DTi} \mathrm{t}_{\mathrm{t}}+\varepsilon_{\mathrm{t}}$

${ }^{\mathrm{a}}{ }^{\mathrm{b}}{ }^{\mathrm{b}}$ and ${ }^{\mathrm{c}}$ indicate significance levels at 1,5 y 10 percent, respectively, as result from the critical values established after 1,500 Monte Carlo iterations.

36 Cf. Zivot and Andrew (1992) and Ben-David, Lumsdaine and Papell (1996), for the consideration of a priori unknown breaks, while Perron (1989) and Crafts and Mills (1996), contrast previously defined breaks. Cubel and Palafox (1998) and, more recently, Pons and Tirado (2006) use the endogenous procedure to establish structural breaks in their historical studies of Spain.

37 There is also a practical reason: a purely statistical approach to the series could mean establishing break points which in fact are caused simply by measurement errors. 
bles in the trend $\left(\mathrm{DTi}_{\mathrm{t}}\right)$ and the level $\left(\mathrm{DUi}_{\mathrm{t}}\right)$ which take on the values $\mathrm{DTi}_{\mathrm{t}}$ $=\left(\mathrm{t}-\mathrm{TB}_{\mathrm{i}}\right)$ and $\mathrm{DUi}_{\mathrm{t}}=1$, if $\mathrm{t} \geqslant \mathrm{TBi}$, and 0 , otherwise; where $\mathrm{TBi}(\mathrm{i}=1,2)$ is the specific time of the break. The structural breaks have been introduced exogenously and different alternatives have been chosen according to the conventional cut-off dates suggested by economic historians ${ }^{38}$. The break dates accepted are those which maximize the value for the statistic $t$ in the parameter corresponding to the lagged GDP variable. The statistical significance of the breaks compares favourably with the critical values obtained using a Monte Carlo simulation ${ }^{39}$. The value of the statistic $t$ for the lagged variable $\left(\mathrm{Y}_{\mathrm{t}-1}\right)$ has significance levels of 10 and 5 percent for absolute GDP and GDP per capita respectively. It follows that as the lagged variable is significantly different from 0 , the existence of a unit root in the presence of structural change can be rejected. The proposed structural breaks are all significant at 5 and 1 percent. The absolute and per capita GDP series are trend stationary with structural breaks in level (1936) and in trend (1951 and 1975) ${ }^{40}$. The segmented trend of the economy is obtained using the regression equation featured in Table A.3. The growth rates for each of the main phases identified for Spain's economic progress were derived by adding cumulatively the parameters of each dummy variable indicating a break in trend (DTit) to the parameter of the time variable. The change in level (DUit) caused by the Civil War influences these values.

TABLE A.3

TREND GROWTH REGRESSION. 1850-2000

(dependent variable: $\ln \mathrm{Y}_{\mathrm{t}}$ )

\begin{tabular}{|l|r|r|r|r|}
\hline \multirow{2}{*}{ variable } & \multicolumn{2}{c|}{ GDP } & \multicolumn{2}{c|}{ Per Capita GDP } \\
\cline { 2 - 5 } & coefficient & t statistic & coefficient & t statistic \\
\hline constant & -21.0503 & -43.04 & -13.4825 & -33.65 \\
time & 0.0155 & 59.84 & 0.0100 & 47.21 \\
$\mathrm{DU}_{1936}$ & -0.2338 & -11.42 & -0.3163 & -19.53 \\
$\mathrm{DT}_{1951}$ & 0.0480 & 62.65 & 0.0423 & 58.34 \\
$\mathrm{DT}_{1975}$ & -0.0319 & -26.62 & -0.0252 & -20.81 \\
\hline $\mathrm{R}^{2}$ ajusted & 0.997 & & 0.995 & \\
F statistic & 12392 & & 7024 & \\
\hline
\end{tabular}

38 The dates for which structural breaks (TBi) have been investigated are: 1866-68, 187173, 1883-85, 1891-92, 1898-1900, 1913-14, 1919-20, 1929-30, 1935, 1940, 1950-51, 1960-61, 1973-75, 1985-86, 1991-92.

39 I Thank Isabel Sanz for her help with these Monte Carlo experiments.

40 Pons and Tirado (2006) find structural breaks in 1935, 1940 and 1960 


\section{Procedures and Sources for Table 6}

\section{Econometric Procedures}

Growth of income per head is determined by a distinctive set of economic variables:

$$
G Y=g_{1}\left[\alpha, C_{i t}\right]+g_{2}\left[\beta, A_{i t}\right]+g_{3}\left[\gamma, R_{i t}\right]+g_{4}\left[\mu_{\mathrm{i}}, V_{i t}\right]
$$

where $\alpha, \beta$ and $\gamma$ are vectors of time and cross-country invariant parameters; $C_{i t}$ is the set of variables representing catching up or conditional convergence, that is, the initial levels of income and schooling; $A_{i t}$ is a set of variables which represents the accumulation process, i.e., the ratio of investment to GDP and population growth; and $R_{i t}$ is a set of variables representing resource allocation processes. Finally, $\mu_{i}$ is a time invariant, but cross-country variant, vector of parameters, and $V_{i t}$ represents a set of explanatory variables, including a stochastic disturbance (which incorporates policy, institutions, political instability and so on).

The aim of our econometric exercise is to find empirical regularities in economic growth for our set of European countries. Thus, according to our specification, the rate of growth of income per head is determined by a set of economic variables accounting for conditional convergence, accumulation and resource allocation, and a residual that incorporates institutional change. Behind the equation lies, nevertheless, a reduced form of a non-specified growth model. This approach raises theoretical problems, as regards the interpretation of the parameters. Table 6 reports regression results for the growth rate of real per capita GDP. The same econometric specification has been estimated for all the countries in the sample. Equations 1 to 3 show equations in which the growth rate of GDP per capita, as the dependent variable, is regressed on the initial levels of (log of) income (LY90) and primary and secondary school enrolment (ESCOLAR), as a proxy to human capital, the ratio of gross domestic investment to GDP, which enters into the regressions as a decade average (in order to represent the steady-state level of investment) (SINVT). Finally, a time trend dummy was included to capture temporal changes in the dependent variable not associated with variation in the independent variable (TBIAS). Lagged and initial values of the explanatory variables have been used as instruments.

Resource allocation indicators are added in Equations 4 and 5 to take into account the shift of resources away from agriculture, and they are proxied by the initial share of labour force in agriculture (AGLAB) and the average ratio of agricultural to industrial output (LSPOI). Moreover, openness has been measured by the growth rate of the exports ratio to GDP (GXB). Finally, I allowed for a boost to growth from post-war episodes of reconstruction, the 1920's and 1950's, using alternatively, as pro- 
xies, the post-war / pre-war per capita income ratio (i.e., 1920/1913 income ratio for the 1920s and 1950/1938 income ratio for the 1950s) (RCNSTRC), and its quadratic term (RCNSTRC2) to incorporate its diminishing impact on growth (Equation 4), and, then, a human to physical capital ratio (HPK), proxied by the post-war to the pre-war (ESCOLAR / SINVT) ratio. Thus, for the 1950s, it is the 1950/1938 ratio, and for the 1920s, the 1920/1913 ratio, otherwise takes zero value.

The estimated coefficient of the initial level of per capita real GDP is negative, meaning that countries with a lower starting GDP per head grow faster. When we accept that countries have different steady-state equilibrium, convergence accelerates. Thus, the magnitude of the implicit speed of convergence implied by equations (1) to (3) is slightly below the usual 2 percent, but when structural change indicators are included in equations (4) and (5), the speed of convergence is higher. Fixed effects, correlated with the initial level of income, seem to be captured by the structural indicators and this accounts for the large differential in the speed of convergence between equations (1) to (3) and (4) and (5).

The remaining coefficients show the expected relations, positive for accumulation and openness, and negative for tying up resources to agriculture. For the coefficient of LSPOI, it suggests that countries with a high agricultural-industrial output ratio tend to grow more slowly. A surprising finding is the coefficient of AGLAB, since it suggests that a large initial share of labour force in agriculture reduces the growth rate, when just the opposite would be expected, i.e., countries with a large agricultural sector in the initial period would have more opportunities to grow faster by shifting labour towards the industrial sector. The reconstruction dummies suggest that reconstruction processes had a positive effect on growth.

As regards the lack of statistical significance of the human capital proxy, two possible explanations can be suggested: that it is a flow variable and, hence, captures poorly a stock variable. Unfortunately years of education are lacking for such a long time span. The alternative, the literacy rate, loses its meaning as a human capital measure as we approach the present and all countries become literate. Another explanation could be that human capital is somehow (inversely) capture by AGLAB, as the higher the share of labour in agriculture, one can presume, the lower the endowment of human capital. This would, then, explain the negative sign of AGLAB

\section{Sources}

GDP per head (LY90): For each country, levels of Gross Domestic Product per capita expressed in 1990 Geary-Khamis dollars adjusted for purchasing power (OECD, National Accounts, 1960-1990. Main Aggregates. Paris: OECD 1992, vol. 1) have been projected backwards 
with volume series derived from historical national accounts. Data derive from the sources listed below. Otherwise they come from Maddison, World Economy.

Austria, GDP for Imperial (Habsburg) Austria is from Kausel, A., Österreichs Volkseinkommen 1830 bis 1913, in Geschichte und Ergebnisse der zentralen amtlichen Statistik in Österreich 1829-1979, Ed. Österreichisches Statistisches Zentralamt, Beitraege zur öesterreichischen Statistik, Heft 550. Vienna 1979, for 1850-1860, and from Schulze, M.S., Patterns of growth and stagnation in the late nineteenth century Habsburg economy, European Review of Economic History, vol. 4, 2000: 3, 311-340, for 18701913. Belgium, Horlings, E., The Contribution of the service sector to Gross Domestic Product in Belgium 1835-1990. Utrecht: Universiteit Utrecht 1997 (mimeo), 1830-1913; average of GDP estimates from Buyst, E., New GNP estimates for the Belgian economy during the Interwar period Review of Income and Wealth, vol.43, 1997: 357-375, (income and expenditure approaches) and Horlings, Contribution, (output), for 1925-1938. Czechoslovakia, Lethbridge, E., National income and product, in Economic History of Eastern Europe, 1919-1975, II., Economic Structure and Performance between the two Wars, Eds. M. C. Kaser and E. A. Radice. Oxford: Clarendon Press 1985, pp. 532-597. France, Toutain, J.C., Le produit intérieur brut de la France, 1789-1990, Economies et Societés. Histoire Economique Quantitative, 1, 1997: 11, 5-136. Finland, Hjerppe, R., Finland's Historical National Accounts 1860-1994: Calculation Methods and Statistical Tables. Jyväskylä: J.Y.H.L. 1996. Germany, 1850-1890, Hoffmann, W.G., Grumbach, F. Hesse, H., Das Wachstum der Deutschen Wirtschaft seit der Mitte des 19. Jahrhunderts. Berlin: Springer 1965; 19001950, Spoerer, M., Weimar's investment and growth record in intertemporal and international perspective, European Review of Economic History, vol. 1, 1997: 271-297, and Ritschl, A. and M. Spoerer, Das Bruttosozialprodukt in Deutschland nach den amtlichen Volseinkommesund Sozialproduktsstatistiken 1901-1995, Jahrbuch für Wirtschaftsgeschichte, vol. 2, 1997: 27-54. 1850-1900, GNP at market prices was obtained by re-scaling NNP with the GNP/NNP ratio for 1901-13, from Spoerer, Weimar's investment. 1850-1913, GDP at market prices was computed from the GNP estimates and from data on net factor payments abroad taken from Hoffmann et al., Das Wachstum, and Ritschl, A., «Some National Accounts for Interwar Germany, 1925-1938»1991 (mimeo). West Germany figures since 1950 include the Saar and West Berlin and figures for West Germany in 1950-55 had to be re-scaled by 8.6 percent. Greece, Kostelenos, G., Money and Output in Modern Greece, 1858-1938. Athens: Centre of Planning and Economic Research (KEPE) 1995, 1860-1938. Hungary, Imperial (Habsburg) Hungary 1870-1913 at 1913 prices from Schulze, Patterns of growth and stagnation. Modern (Republic of) 
Hungary 1913-1938, from Eckstein, A., National income and capital formation in Hungary, 1900-1950, Income and Wealth, vol. V, 1955: 150-223, for the country as defined by the treaty of Trianon (1919 reflated by 5 percent to allow for GNP-NNP differences. Netherlands, Smits, J.P., E. Horlings and J.L. van Zanden, Dutch GNP and its Components, 1800-1913. Groningen: Groningen Growth and Development Centre Research Monograph no. 5, 2000; Bakker, G.P., den, T.A. Huitker and C.A. van Bochove, The Dutch economy 1921-1938: Revised macroeconomic data for the interwar period, Review of Income and Wealth vol. 36, 1990, 187-206. Norway, Grytten, O.H., The gross domestic product for Norway 1830-2003, in Historical Monetary Statistics for Norway 1819-2003, Eds. Eitrheim, Ø., J.T. Klovland and J.F. Qvigstad, Norges Bank Occasional Papers no. 35, Oslo: Norges Bank 2004, pp. 241-288. Portugal, Lains, P., Growth in a protected environment: Portugal, 1850-1950, Research in Economic History, vol. 24, 2006: 121-163, 1850-1910; 1910-1955, Batista, D., C. Martins, M. Pinheiro and J. Reis, New Estimates of Portugal's GDP 1910-1958. Lisbon: Banco de Portugal 1997; 1955-1990, Pinheiro, M., Séries longas para a economia portuguesa pós II Guerra Mundial. I. Séries Estatísticas. Lisbon: Banco de Portugal 1997. Russia, (Imperial) Gregory, P., Russian National Income. Cambridge: Cambridge University Press 1982, 1885-1913. Spain, Prados de la Escosura, L., El progreso económico en España, 1850-2000. Madrid: Fundación BBVA 2003. Sweden, Krantz, O., Swedish historical national accounts 1800-1990. Aggregate output series. Umea: Umea University 1997(mimeo). United Kingdom, Mitchell, B.R., British Historical Statistics. Cambridge: Cambridge University Press 1988.

Ratio of gross domestic investment to GDP, in current prices, calculated as ten-year averages (SINVT): Mitchell, International Historical Statistics; Flora, P., State, Economy and Society in Western Europe, 1815-1975. Frankfurt: Campus 1987; Maddison, A., A long run perspective on saving, Institute of Economic Research Faculty of Economics, University of Groningen, Research Memorandum, no. 443, 1990; and OECD, National Accounts, for most of the countries. Spanish figures are from Prados de la Escosura, Progreso económico. French figures were derived from Levy-Leboyer, M. and F. Bourguignon, L'économie Francaise au XIXe siècle. Analyse Macro-économique. Paris: Economica 1985, up to 1913, and Carre, J.J., P. Dubois and E. Malinvaud, French Economic Growth. Oxford: Oxford University Press 1976, for the remaining years. Figures for Italy are from Ercolani, P., Documentazione statistica di base, in Lo sviluppo economico in Italia. Storia dell' economia italiana negli ultimi ciento anni, Ed. G. Fua. Milano: Franco Angeli 197881, 3 vols, III, pp. 388-472, for 1861-1890 and Rossi, N., A. Sorgato and G. Toniolo, Italian historical statistics, 1890-1990, Università degli Studi di Venezia, Dipartimento di Scienze Economiche, Nota di Lavoro, 92.18, 
1992, for 1890-1990. In the case of Portugal, Batista et al., New Estimates, Pinheiro, Séries longas, and Cartaxo, R.J. and Da Rosa, N.E., Series longas para as contas nacionais portuguesas 1958-1985, Banco do Portugal, Documento de Trabalho 15, 1986, were the references used. For United Kingdom, Feinstein, C.H., National Income, Expenditure and Output of the UK, 1855-1965, Cambridge: Cambridge University Press 1972, and Mitchell British Historical Statistics.

Population growth (GPOP1): Computed from population figures adjusted to take into account the territorial changes provided by Maddison, World Economy, and Mitchell, B.R., International Historical Statistics: Europe 1750-2000. New York: Palgrave Macmillan 2003. Nicolau, R., Población, salud y actividad, in Estadísticas Históricas de España. Siglos XIX-XX, Eds. A. Carreras and X. Tafunell. 3 vols., Madrid: Fundación BBVA 2005, II, pp. 77-154, completes the figures for Spain.

School enrolment (ESCOLAR) refers to population attending primary and secondary school as a percentage of total population between 5 and 19 years old. Figures are from Mitchell, International Historical Statistics, Flora, State, Economy and Society, World Bank, WORLD BANK (various years). Social Indicators of Development. Baltimore: Johns Hopkins University Press, UNITED NATIONS (various years). Statistical Yearbook. New York: U.N.; UNESCO (various years). Statistical Yearbook. Paris: Unesco.

Labour share in agriculture expressed as a percentage of total labour force (AGLAB): from Bairoch et al., Working Population, Flora, State, Economy and Society, Mitchell, International Historical Statistics, and OECD, Labour Force Statistics, 1969-1990. Paris: OECD 1992. National figures were completed with Lains, Growth in a protected environment, and Nunes, A.B., A evoluçâo da estrutura, por sesos, da populaçâo activa en Portugal —um indicador do crecimento económico (1889-1981)—, Análise Social, vol. 26, 1991: 707-722, for Portugal; Toutain, produit intérieur brut, for France; Zamagni, V., A Century of Change: Trends in the Composition of Labour Force, 1881-1981, Historical Methods, vol. 44, 1987: 36-97, and Vitali, Vitali, O., Aspetti dello sviluppo economico italiano alla luce della ricostruzione della popolazione attiva. Roma: ISTAT 1970, for Italy; Prados de la Escosura, Progreso económico, for Spain.

Index of production orientation (log of agricultural-industrial output ratio), calculated as ten-year averages (LSPOI): Shares of agriculture (which includes forestry and fishing), and Industry (mining, manufacture, construction and utilities) in GDP at current prices are taken from Mitchell, International Historical Statistics, Flora, State, Economy and Society, and OECD, Historical Statistics, 1960-1989. Paris: OECD 1991. In the case of Spain, Prados de la Escosura, Progreso económico. For France, Toutain, produit intérieur brut, and for Germany prior to World 
War I, Tilly, R., Capital formation in Germany in the nineteenth century, in Cambridge Economic History of Europe, Eds. M.M. Postan and P. Mathias. Cambridge: Cambridge University Press 1978, VII, Part 1. pp. 382-441, and Fremdling, R., German national accounts for the 19th and early 20th century. A critical assessment, Vierte Jahrschrift für Socialand Wirtschaftsgeschichtes, vol. 75, 1988: 339-355.

Growth rate of exports ratio to GDP (GXB): Derived from exports and GDP (see above). Figures for exports come from Bairoch, P., Commerce extérieur et développement économique de l'Europe au XIXe siècle. Paris: Mouton 1976; Kuznets, S., Quantitative Aspects of the EconomicGrowth of Nations, X: Level and Structure of Foreign Trade: Long-Term Trends, Economic Development and Cultural Change, vol. 15, 1967: 2; Mitchell, International Historical Statistics; OECD, National Accounts; OECD, Monthly Statistics of Foreign Trade. Paris: OECD 1992. For Portugal figures are derived from Nunes, A.B., E. Mata and N. Valerio, Portuguese economic growth 1833-1985, Journal of European Economic History, vol. 18, 1989: 291-330. Spanish figures are from Prados de la Escosura, Progreso económico, and Tena, A., Sector exterior, in Estadísticas Históricas de España. Siglos XIX-XX, Eds. A. Carreras and X. Tafunell. 3 vols., Madrid: Fundación BBVA 2005, II, pp. 573-644.

\section{REFERENCES}

Álvarez-Nogal, C. y Prados De la Escosura, L. (2007): Searching for the Roots of Spain's Retardation: Spain in European Perspective, 1500-1850. Universidad Carlos III: Working Papers in Economic History 07-06.

ARK, B. VAN (1996): «Sectoral Growth Accounting and Structural Change in Post-war Europe», in: B, van Ark and N. Crafts (Eds.), Quantitative Aspects of Post-war European Economic Growth. Cambridge, Cambridge University Press and CEPR, pp. 84-164.

- (1995): «Producción y productividad en el sector manufacturero español. Un análisis comparativo 1950-1992». Información Comercial Española, 746, pp. 67-77.

Barciela López, C. (1986): «Introducción», in: R. Garrabou, Barciela, C., JimÉnez Blanco, J. I. (Eds.), Historia agraria de la España contemporánea. 3. El fin de la agricultura tradicional (1900-1960). Barcelona, Crítica, pp. 383-454.

Ben-David, D.; Lumsdaine, R. L., and Papell, D. H. (1996): «The Unit Root Hypothesis in Long-term Output: Evidence from two Structural Breaks for 16 Countries», Centre for Economic Policy Research, Discussion Paper Series n. ${ }^{\circ} 1336$

Bloom, D. E., and Williamson, J. G. (1998): «Demographic Transitions and Economic Miracles in Emerging Asia». World Bank Economic Review, 12, pp. 419-455.

Bordo, M. D., and RockOFF, H. (1996): «The Gold Standard as a "Good Housekeeping Seal of Approval"». Journal of Economic History, 56, pp. 389-428.

BROADBERRY, S. N. (1998): "How Did the United States and Germany Overtake Britain? A Sectoral Analysis of Comparative Productivity Levels». Journal of Economic History, 58, pp. 375-407. 
Calvo González, O. (1999): «The Impact of American Aid in the Spanish Economy in the 1950s». LSE Working Papers, 47.

- (2001): «iBienvenido Mr Marshall! La ayuda económica americana y la economía española en la década de 1950». Revista de Historia Económica (special issue), 18, pp. 253-275.

Campbell, J. Y., and Perron, P. (1991): «Pitfalls and Opportunities: What Macroeconomists Should Know about Unit Roots», in: O. J. BLANCHARD and S. FISHER (Eds.), NBER Macroeconomic Annual, Cambridge, M. A.: M.I.T., vol. 7, pp. 141-201.

CARRERAS, A. (1987): «An Annual Index of Spanish Industrial Output», in: SÁNCHEZAlbornoz, N. (Ed.), The Economic Modernization of Spain, 1830-1930. New Cork, New York University Press, pp. 75-89.

- (1992): «La producción industrial en el muy largo plazo: una comparación entre España e Italia de 1861 a 1980», in: Prados DE LA Escosura, L., ZAMAGNI, V. (Eds.), El desarrollo económico en la Europa del sur: España e Italia en perspectiva histórica. Madrid, Alianza, pp. 173-210.

CARreras, A., y Tafunell, X. (2003): Historia Económica de la España contemporánea, Barcelona, Crítica.

Catalan, J. (2003): «La reconstrucción franquista y la experiencia de la Europa occidental, 1934-1959», in: BARciela, C. (Ed.), Autarquía y mercado negro. El fracaso económico del primer franquismo, 1939-1959. Barcelona, pp. 123-68.

CoATsworth, J. H. (1990): «Los orígenes del atraso. Nueve ensayos de historia económica de México en los siglos XVIII y XIX». México D. F., Alianza Editorial Mexicana.

Comín, F. (1987): «La economía española en el período de entreguerras (1919-1935)», in: NADAL, J.; CARRERAS, A., y SUDRIÀ, C. (Eds.), La economía española en el siglo XX. Una perspectiva histórica. Barcelona, Ariel, pp. 105-149.

- (1992): «Una reconstrucción diferente en la España de la postguerra», Estudis d'Historia Económica, 2, pp. 63-78.

- (1994): «El papel del presupuesto en el crecimiento económico español: una visión a largo plazo». Revista de Historia Económica, 12, pp. 283-314.

Comín, F., y MARTín ACEÑA, P. (1984): «La política monetaria y fiscal durante la Dictadura y la Segunda República». Papeles de Economía Española, 20, pp. 236-261.

Crafts, N. (1992): «Productivity Growth Reconsidered». Economic Policy, 15, pp. $388-426$.

Crafts, N., and Mills, T. C. (1996): «Europe's Golden Age: An Econometric Investigation of Changing Trend Rates of Growth», in: VAN ARK, B., CRAFTS, N. (Eds.), Quantitative Aspects of Post-war European Economic Growth. Cambridge, Cambridge University Press and CEPR, pp. 415-31.

Crafts, N., and Toniolo, G. (1996): «Postwar Growth: An Overview», in: Crafts, N., Toniolo, G. (Eds.), Economic Growth in Europe since 1945. Cambridge, Cambridge University Press and CEPR, pp. 1-37.

CRouzet, F. (1967): «England and France in the Eighteenth Century: A Comparative Analysis of Two Economic Growths", in: Hartwell, R. M. (Ed.), The Causes of the Industrial Revolution in England. London, Methuen, pp. 139-74.

Cubel Montesinos, A., y Palafox GámiR, J. (1998): «La continuidad del crecimiento económico en España. 1850-1936». Revista de Historia Económica, 16, pp. 619643.

DumKe, R. H. (1990): «Reassessing the Wirtschaftswunder: Reconstruction and Postwar Growth in West Germany in an International Context». Oxford Bulletin of Economics and Statistics, 52, pp. 451-491.

Eichengreen, B. (1992): «The Origins and Nature of the Great Slump Revisited». Economic History Review, 45, pp. 213-239. 
Eichengreen, B., and Uzan, M. (1992): «The Marshall Plan: Economic Effects and Implications for Eastern Europe and the Former USSR». Economic Policy, 14, pp. 13-75.

Fraile BALBín, P. (1991): «Industrialización y grupos de presión». La economía politica de la protección en España, 1900-1950. Madrid, Alianza.

- (1998): La retórica contra la competencia en España (1875-1975). Madrid, Fundación Argentaria/Visor.

- (1999): «Spain: Industrial Policy under Authoritarian Politics», in: Foreman-PecK, J., Federico, G. (Eds.), European Industrial Policy. The Twentieth-Century Experience. Oxford, Oxford University Press, pp. 233-67.

Fraile Balbín, P., and Escribano, A. (1998): "The Spanish 1898 Disaster: The Drift Toward, National-Protectionism», in: O’Brien, P. K., Prados DE LA Escosura, L. (Eds.), The Costs and Benefits of European Imperialism from the Conquest of Ceuta, 1415, to the Treaty of Lusaka, 1974. Revista de Historia Económica, (special issue) 16, pp. 265-290.

GANDOy Juste, R. (1988): «Evolución de la productividad global en la industria española. Un análisis desagregado para el período 1964-1981». Universidad Complutense de Madrid. Unpublished Doctoral Dissertation.

García SANTos, N., y MarTín AcEÑa, P. (1990): «El comportamiento del gasto público en España durante la II República, 1931-1935». Revista de Historia Económica, 8, pp. 397-415.

Gregory, P. R. (1994): Before Command. An Economic History of Russia from Emancipation to the First Five-year Plan. Princeton, N.J., Princeton University Press.

Haber, S., and Razo, A. (2000): «Industrial Prosperity under Political Instability: An Analysis of Revolutionary Mexico» in: Bueno DE Mesquita, B. and Root, H. L. (Eds.), Governing for Prosperity. New Haven, Yale University Press 2000, pp. 106152.

Higgins, M., and Williamson, J. G. (1997): «Age Structure Dynamics in Asia and Dependence on Foreign Capital». Population and Development Review, 23, pp. 261-293.

Kindleberger, C. P. (1967): European Postwar Growth: The Role of Labor Supply. Princeton, National Bureau of Economic Research.

López GARCíA, S. M. (1991): «La organización de la investigación científica y técnica tras la Guerra Civil: contrastes y similitudes con los logros de las primeras décadas del siglo XX». Actas del Encuentro de Historia Económica. Valencia, UIMP.

- (1996): "La investigación científica y técnica antes y después de la Guerra Civil», in: Gómez MendozA, A. (Ed.), Economía y sociedad en la España contemporánea. Madrid, Síntesis, pp. 265-275.

Maddison, A. (1991): Dynamic Forces in Capitalist Development. Oxford, Oxford University Press.

- (1996): "Macroeconomic Accounts for European Countries», in: VAN ARK, B., CRAFTs, N. (Eds.), Quantitative Aspects of Post-war European Economic Growth. Cambridge, Cambridge University Press and CEPR, pp. 27-83.

- (2001): The World Economy. A Millennial Perspective. Paris, OECD.

- (2003): The World Economy. Historical Statistics. Paris, OECD.

MALEFAKIS, E. (1987): "La economía española y la guerra civil», in: NADAL, J., CARreras, A., Sudrià, C. (Eds.), La economía española en el siglo XX. Una perspectiva histórica. Barcelona, Ariel, pp. 150-163.

Maluquer de Motes Bernet, J. (1999): «El impacto de las guerras coloniales de fin de siglo sobre la economía española», in: TEDDE. P. (Ed.), Economía y colonias en la España del 98. Madrid, Síntesis 1999, pp. 101-121. 
Martín Aceña, P. (1984): La política monetaria en España, 1919-1935. Madrid, Instituto de Estudios Fiscales.

- (1994): «Spain during the Classical Gold Standard Years, 1880-1914», in: Bordo, M. D., Capie, F. (Eds.), Monetary Régimes in Transition. Cambridge, Cambridge University Press, pp. 135-172.

- (1999): «The Spanish Monetary Experience, 1848-1914», in: MARTín AcEÑA, P., REIs, J. (Eds.), Monetary Standards in the Periphery. Paper, Silver, and Gold, 18541933. London, Macmillan, pp. 112-51.

Matthews, R. C. O.; Feinstein, C. H., and Odling-Smee, J. C. (1982): British Economic Growth 1856-1973. Oxford, Clarendon Press.

Myro, R. (1983): «La evolución de la productividad global de la economía española en el período 1965-1981». Información Comercial Española, 594, pp. 115-127.

OCDE (1999): Purchasing Power Parities and Real Expenditures. 1996 Results. París, OCDE.

O'Rourke, K., and Williamson, J. G. (1999): Globalization and History. The Evolution of Nineteenth Century Atlantic Economy. Cambridge, MA, M.I.T. Press.

Ortega, J. A., y Silvestre, J. (2006): «Las consecuencias demográficas», in: MarTín Aceña, P., Martínez Ruiz, E. (Eds.), La economía de la guerra civil. Madrid, Marcial Pons, pp. 53-105.

NúÑEZ, C. E. (2003): «El capital humano en el primer franquismo», in: BARCIELA, C. (Ed.), Autarquía y mercado negro. El fracaso económico del primer franquismo, 1939-1959. Barcelona, Crítica, pp. 28-53.

Palafox, J. (1991): Atraso y democracia. La Segunda República y la economía española, 1892-1936. Barcelona, Crítica.

- (1999): «Proteccionismo y librecambio», in: ANEs, G. (Ed.), Historia Económica de España. Siglos XIX y XX. Barcelona, Galaxia Gutemberg/Círculo de Lectores, pp. 251-287.

PARDOS, E. (1998): La incidencia de la protección arancelaria en los mercados españoles (1870-1913). Madrid, Banco de España, Estudios de Historia Económica, n. ${ }^{\circ}$ 37.

Pérez Moreda, V. (1999): «Población y economía en la España de los siglos XIX y XX», in: ANes, G. (Ed.), Historia Económica de España. Siglos XIX y XX. Barcelona, Galaxia Gutemberg/Círculo de Lectores, pp. 7-62.

Perron, P. (1989): «The Great Crash, the Oil Price Shock, and the Unit Root Hypothesis». Econometrica, 57, pp. 1361-1401.

Plá BRugat, D. (1994): «Características del exilio en México en 1939, Una inmigración privilegiada», in: LiDA C. E. (Ed.), Comerciantes, empresarios y profesionales españoles en México en los siglos XIX y XX. Madrid, pp. 218-231.

- (1999): Els exiliats catalans. Un estudio de la emigración republicana en México. México D. F., INAH.

Pons, J, y TiRado, D. (2006): «Discontinuidades en el crecimiento económico en el periodo 1870-1994: España en perspectiva comparada». Revista de Economía Aplicada, 14, 40, pp. 137-156.

Prados de la Escosura, L. (1988): De imperio a nación. Crecimiento y atraso económico en España, 1780-1930. Madrid, Alianza.

- (2000): «International Comparisons of Real Product, 1820-1990: An Alternative Data Set». Explorations in Economic History, 37, pp. 1-41.

- (2003): El progreso económico de España, 1850-2000. Madrid, Fundación BBVA.

- (2006): «Growth, Inequality, and Poverty in Spain, 1850-2000: Evidence and Speculation», Universidad Carlos III Working Papers in Economic History, 06/03.

- (2007a): «La posición internacional de la economía española, 1850-1935» (processed). 
- (2007b): «Growth, Catching Up and Structural Change in Europe, 1850-1990» (processed).

Prados de la Escosura, L., y Tena, A. (1994): «Protectionism in Spain, 1869-1930», in: Lindert, P. H., Nye, J. V., and Chevet, J. M. (Eds.), Political Economy of Protectionism and Commerce, 18th-20th Centuries. Milano, Universitá Bocconi, pp. 63-76.

Prados de la Escosura, L., and SanZ, J. C. (1996): «Growth and Macroeconomic Performance in Spain (1939-1993)», in: Crafts, N., Toniolo, G. (Eds.), Economic Growth in Europe since 1945. Cambridge, Cambridge University Press and CEPR, pp. 355-387.

Prados DE LA Escosura, L., y Rosés, J. R. (2007): «El capital en España, 1850-2000» (processed).

RoldÁn, S., y GaRcía Delgado, J. L. (1973): «La formación de la sociedad capitalista en España, 1914-1920». Madrid, Cajas de Ahorro Confederadas, 2 vols.

Rosés, J. R. (2003): «Regional Industrialisation without National Growth». The Catalan Industrialisation and the Growth of the Spanish Economy. Universitat Pompeu Fabra Working Papers.

Rosés, J. R., and SÁnchez-Alonso, B. (2004): «Regional Wage Convergence in Spain, 1850-1930». Explorations in Economic History, 41, pp. 404-425.

SAN JUAN, C. (1987): «Eficiencia y rentabilidad de la agricultura española». Madrid, Ministerio de Agricultura.

SÁNCHEZ-Alonso, B. (2000): «European Emigration in the Late Nineteenth Century: the Paradoxical Case of Spain». Economic History Review, 53, pp. 309-330.

SÁNCHEZ Asiaín, J. A. (1999): «La economía en la guerra civil española (1936-1939)», in: ANEs, G. (Ed.), Historia Económica de España. Siglos XIX y XX. Barcelona, Galaxia Gutemberg/Círculo de Lectores, pp. 563-624.

SANCHIS LLOPIS, M. T. (2001): «Transferencias intersectoriales de productividad en la economía española, 1958-1975». Revista de Historia Industrial, 19-20, pp. 275-301.

SuÁrez BERnALdo de Quirós, J. (1992): «Economías de escala, poder de mercado y externalidades: medición de las fuentes del crecimiento español». Investigaciones Económicas, 16, pp. 411-441.

SUDRIÀ, C. (1990): «Los beneficios de España durante la Gran Guerra. Una aproximación a la balanza de pagos española, 1914-1920». Revista de Historia Económica, 8, pp. 363-396.

Tena Junguito, A. (1999): «Un nuevo perfil del proteccionismo español durante la Restauración, 1875-1930». Revista de Historia Económica, 17, 1999: pp. 579-621.

TORTella, G. (1994a): El desarrollo de la España contemporánea. Historia económica de los siglos XIX y XX. Madrid, Alianza.

- (994b): "Patterns of Economic Retardation and Recovery in South-western Europe in the Nineteenth and Twentieth Centuries». Economic History Review, 47, pp. 1-21.

Velarde Fuertes, J. (1968): Política económica de la Dictadura. Madrid, Guadiana.

- (1993): «Convergencias y divergencias de la economía española: comentario a una intervención del profesor Comín». Papeles de Economía Española, 57, pp. 57-72.

Williamson, J. G. (1998): «Growth, Distribution, and Demography: Some Lessons from History». Explorations in Economic History, 35, pp. 241-271.

- (2002): «Land, Labor, and Globalization in the Third World, 1870-1940». Journal of Economic History, 62, pp. 55-85.

Zivot, E., and ANDREWS, D. (1992): «Further Evidence on the Great Crash, the Oil Price Shock, and the Unit Root Hypothesis». Journal of Business and Economic Statistics, 10, pp. 251-270. 



\section{INFORMACIÓN PARA LOS AUTORES Normas para el envío de originales}

1. Temas de interés. La Revista de Historia Económica. Journal of Iberian and Latin American Economic History publica artículos de investigación sobre historia económica, historia del pensamiento económico y todos aquellos campos de la economía relacionados con el análisis del largo plazo. El ámbito geográfico de sus artículos lo constituyen, preferentemente, la Península Ibérica e Iberoamérica, así como aquellas áreas, más amplias, que engloban a las anteriores. Los trabajos que se envíen a la Revista han de ser originales, no publicados ni sometidos a consideración para su publicación en otra parte.

Esta Revista está incluida en ECON-LIT, LATIN INDEX, IBSS y CINDOC-ISOC.

2. Proceso de evaluación y tiempos de publicación. Los editores se proponen ser rigurosos y transparentes en el proceso de revisión haciendo explícito el protocolo de evaluación desde el acuse de recibo hasta la aceptación final (ver Proceso de Revisión). Así como razonablemente expeditivos entre la recepción de la versión final del manuscrito, con la incorporación de las revisiones requeridas para la aceptación, y la publicación final que llevará entre dos y tres números (es decir entre ocho y doce meses).

3. Envío. Los originales se enviarán en español, inglés o portugués, escritos en Microsoft Word. Se enviarán preferentemente por correo electrónico a la dirección rhe-jilaeh@uc3m.es; excepcionalmente, se podrán enviar también en papel (una copia), junto con un archivo en disquete o CD ROM, a nombre del Director responsable de la Revista y a las señas siguientes:

Prof. Antonio Tena (antonio.tena@uc3m.es).

Departamento de Historia Económica.

Universidad Carlos III de Madrid.

C/ Madrid, 126.

E-28903 Getafe (España).

RHE-JILAEH acusará recibo de todos los originales en un plazo no superior a diez días desde su recepción.

4. Formato. Los originales deberán ir escritos a doble espacio, en letra Times New Roman tamaño 12. La extensión total no superará las 30 páginas (10.000 a 12.000 palabras), incluidos gráficos, cuadros, notas a pie de página, bibliografía y apéndices en su caso. La primera página incluirá el título, nombre del autor o autores, filiación académica, dirección tanto de correo ordinario como de correo electrónico, y número(s) de teléfono. En una segunda página se presentarán dos resúmenes, en español (portugués) e inglés, de unas 120 palabras cada uno, entre tres y cinco palabras clave (en los dos idiomas) y la(s) clasificación(es) JEL. Con el fin de garantizar el anonimato en el proceso de evaluación, el resto del texto no podrá incluir ninguna mención al autor o autores (incluidas las que se hagan en notas a pie de página) que permita desvelar su identidad. Los originales observarán el siguiente orden: texto con sus notas a pie de página, seguido por apéndices y bibliografía. En la medida de lo posible, los cuadros, gráficos y mapas se insertarán en sus lugares dentro del texto, con el mismo tipo de letra que éste y a tamaño similar; cuando no, deberán ir incluidos al final del texto, o en un archivo separado. Todas las páginas habrán de ir numeradas correlativamente. La notas, debates y ensayos bibliográficos no deberán superar las 10 páginas (3.300-4.000 palabras). 


\section{Normas de edición:}

a. Bibliografía. Las referencias bibliográficas irán ordenadas alfabéticamente por el apellido (en mayúsculas) del autor, bajo el título «Bibliografía» y al final del original. Si se citan dos o más obras de un determinado autor publicadas en el mismo año, éstas se distinguirán por medio de una letra. Ejemplo: Clark (2004a) y Clark (2004b). Las referencias se limitarán a obras citadas en el trabajo. Como ejemplos, se incluyen los siguientes:

MARTÍN ACEÑA, P., y PONS, M. ${ }^{a}$ A. (2005): «El sistema monetario y financiero», en A. Carreras y X. Tafunell (coords.), Estadísticas históricas de España: siglos XIX y XX. Bilbao: Fundación BBVA, pp. 645-706.

FOGEL, Robert W. (1994): «Economic Growth, Population Theory, and Physiology: The Bearing of Long-Term Processes on the Making of Economic Policy». American Economic Review 84 (3), pp. 369-395.

HABER, S.; MAURER, N., y RAZO, A. (2003): The Politics of Properties Rights: Political Instability, Credible Commitments, and Economic Growth in Mexico, 1876-1929. Londres: Cambridge University Press.

Si el artículo incluye referencias a fuentes de archivo, éstas se relacionarán aparte y antes de la Bibliografía, bajo el título de «Fuentes».

b. Notas a pie de página. Todas las notas irán a pie de página, numeradas mediante caracteres arábigos, en formato superíndice y en orden creciente, siempre antes de un punto. En las notas no se incluirán las referencias bibliográficas completas, sino solamente su forma abreviada. Ejemplo: Cubel (2003: 322-325).

c. Citas. Las citas irán entrecomilladas y, cuando excedan de tres líneas, separadas del cuerpo principal del texto. En este último caso, irán sangradas y a espacio sencillo. Cualquier cambio introducido en la cita original deberá indicarse encerrándolo entre corchetes.

d. Figuras. Los cuadros, gráficos y mapas habrán de ser originales; llevarán un encabezamiento breve, irán numerados por orden de aparición en el texto, y especificarán la fuente de la que proceden.

6. Adecuación de los artículos aceptados a las normas de edición. Los autores de los artículos aceptados, en cualquier caso, deberán enviar una nueva versión adaptada al formulario de «normas de edición RHE-JILAEH» en un plazo nunca superior a los diez días.

7. Corrección de pruebas. Los autores de artículos aceptados para publicación podrán ser requeridos para la corrección de pruebas de imprenta, que habrán de ser devueltas en un plazo siempre inferior a los diez días. No se permitirá la introducción de cambios sustanciales en las pruebas, quedando éstos limitados a la corrección de errores con respecto a la versión aceptada.

8. Copyright. Es condición para la publicación que el autor o autores ceda(n) a la Revista de Historia Económica los derechos de reproducción. Si se producen peticiones de terceros para reproducir o traducir artículos o partes de los mismos, la decisión corresponderá al Consejo Editorial.

9. Aviso. Cualquier incumplimiento de las presentes Instrucciones constituirá motivo para el rechazo del original remitido y, como mínimo, será causa de retraso en su proceso. 


\section{SUBMISSION INFORMATION}

1. Topics of interest. The Revista de Historia Económica. Journal of Iberian and Latin American Economic History publishes original research papers on economic history, economic thought and all those areas of economics concerned with longterm analysis. The geographical area addressed in these papers should preferably cover Spanish and Portuguese speaking countries and wider areas including any of these countries. Papers should be original and should be neither published nor be under consideration for publication elsewhere.

This Journal is included in ECON-LIT, LATIN INDEX, IBSS and CINDOC-ISOC.

2. Evaluation process and publication times. The Editors will be rigorous and transparent in the Evaluation Process from the initial receipt to the final acceptance of the manuscript (See Review Process). In addition reasonable expeditious between receipt of the final manuscript, incorporating all required revision for acceptance, and the actual publication, is likely to be two or three issues (ie., eight month to one year).

3. Submission of manuscripts. The manuscripts may be sent in Spanish, English or Portuguese and should preferably be sent by e-mail (rhe-jilaeh@uc3m.es) or, if not, a paper copy (one) together with a Microsoft Word or PDF file on a disk or CD-ROM to the address given below. The graphs, tables and maps which can not be included in the file may be submitted in an additional Microsoft Excel file. The mailing address for submission of manuscripts is:

Prof. Antonio Tena (antonio.tena@uc3m.es).

Departamento de Historia Económica.

Universidad Carlos III de Madrid.

C/ Madrid, 126.

E-28903 Getafe (España).

RHE-JILAEH will acknowledge receipt of all manuscripts within 10 days of reception.

4. Format of submission. Manuscripts are to be submitted in double-spaced Times New Roman point 12 format. The text length should not exceed 30 pages $(10,000$ to 12,000 words), including graphs, tables, footnotes and references. The first page of the paper should include the title, name of author(s), affiliation, full address, e-mail and telephone number. Abstracts in Spanish and English of about 120 words, three to five keywords and JEL classification should be included on a second page. The rest of the manuscript must not include further references to the author(s) or any other mention which may reveal their identity (including references made in footnotes) in order to ensure the anonymous double-blind refereeing process. The structure of papers should be: text with footnotes, followed by appendices, and references (the latter single-spaced). When possible, graphs, tables and maps should be included on the corresponding text page, using the same font and a similar letter size as used in the text. If this is not possible, they may be included at the end of the manuscript or in a separate file. All pages should be numbered. Notes, Surveys and Speculations, Comments and Review of periodical literature should not be more than 10 pages $(3,300-4,000$ words) in length.

\section{Editing guidelianes:}

a. References. Bibliographical references should be listed by surname of author (in capital letters) in alphabetical order under a separate heading at the end of the manuscript. If more than one text by the same author(s) is cited for a 
particular year, then the works should be distinguished by a letter, e.g. Clark (2004a) and Clark (2004b). References are limited to the works cited in the manuscript. The following examples show the format to be applied to references:

MARTÍN ACEÑA, P., y PONS, M. ${ }^{a}$ A. (2005): «El sistema monetario y financiero", in A. Carreras and X. Tafunell (coords.), Estadísticas históricas de España: siglos XIX y XX. Bilbao: Fundación BBVA, pp. 645-706.

FOGEL, Robert W. (1994): "Economic Growth, Population Theory and Physiology: The Bearing of Long-Term Processes on the Making of Economic Policy». American Economic Review 84 (3), pp. 369-395.

HABER, S.; MAURER, N., y RAZO, A. (2003): The Politics of Property Rights: Political Instability, Credible Commitments, and Economic Growth in Mexico, 1876-1929. London: Cambridge University Press.

If the paper includes references to archives, statistics or documentary sources, these should be listed under an additional 'Sources' heading.

b. Footnotes. All notes are to be included as footnotes and numbered in ascending order of appearance in Arabic numbers as superscript before the full stop at the end of the sentence. Complete bibliographical references should not be included in the notes but rather in an abbreviated form, i.e. Cubel (2003: 322-325).

c. Quotations. Literal quotations should be limited and separated from the rest of the text if they exceed three lines. In this case they will be single-spaced and indented. All other quotations may appear in the text and should be clearly identified by quotation marks. Any change(s) made to the original quotation will be indicated by square brackets.

d. Figures. Tables, graphs, and maps should be original. They will include a short title, should be numbered in order of appearance and include the corresponding sources.

6. Upon acceptance of an article. Authors will be asked to resubmit a new version applying the more detailed RHE-JILAEH publication norms.

7. Galley proofs. Once the manuscript has been finally accepted for publication, the author(s) may receive galley proofs which are to be returned within 72 hours. Substantial changes to these proofs are not allowed and changes should be limited to lay-out corrections of the accepted manuscript.

8. Copyright. It is a condition of publication that the author(s) assign(s) copyright of their articles to the Revista de Historia Económica. Journal of Iberian and Latin American Economic History. Requests from third parties to reproduce or translate parts or the whole of articles will be considered by the editorial board.

9. Caveat. Any failure to comply with these guidelines may be considered a reason for rejection of the manuscript submitted or occasion a substantial delay in its processing. 


\section{PROCESO DE REVISIÓN \\ Protocolo de evaluación, revisión de originales y notas de investigación}

RHE- JILAEH, preocupado por la necesidad de acortar los tiempos y mejorar la transparencia del proceso de evaluación de los artículos, cree necesario que los autores y evaluadores sean conscientes del protocolo de evaluación y revisión desde la llegada del original hasta la aceptación final del artículo.

\section{Acuse de recibo}

RHE-JILAEH se compromete a hacer acuse de recibo del manuscrito original al autor en un plazo inferior a diez días si éste es recibido por medios telemáticos.

\section{Evaluación Inicial}

Todos los originales publicados en esta revista serán sometidos al proceso de doble evaluación anónima externa por pares. Previamente, los manuscritos recibidos pasarán por una "pronta revisión» por los editores u otros especialistas del área, usualmente del Comité Editorial, en la que se preserva el anonimato del autor. Esta revisión consiste en discernir su originalidad, relevancia e interés científico, para decidir su paso o no a revisión externa, lo que será notificado a los autores en un plazo inferior a treinta días a partir del acuse de recibo del manuscrito.

\section{Evaluación completa}

Si la revisión inicial es positiva, RHE-JILAEH mandará el manuscrito a dos o más especialistas externos, siguiendo el sistema de revisión por pares con el formato doblemente ciego, lo que no implica compromiso ninguno de aceptación. Sólo después de haber recibido por lo menos dos de los informes pedidos, RHE-JILAEH tomará una decisión sobre el manuscrito. RHE- JILAEH urge a los especialistas a revisar los manuscritos con celeridad (entre tres y cinco semanas), esto permitirá contar con una decisión final en menos de tres meses desde la comunicación a los autores del envío a revisión completa del manuscrito.

En todos los siguientes casos, después de la Evaluación completa del manuscrito, los autores recibirán los comentarios de forma anónima elaborados por los especialistas.

\section{Aceptación y aceptación condicional}

Si las revisiones de los especialistas anónimos son favorables, el manuscrito será usualmente aceptado, condicionado a que el autor considere los comentarios y dudas propuestos en las revisiones. Sólo muy ocasionalmente un manuscrito es aceptado sin requerir al menos ciertas revisiones mínimas.

\section{Revisar y reenviar}

Si las revisiones de los especialistas anónimos son en su mayoría favorables, pero al mismo tiempo varias revisiones y cambios son sugeridos, el manuscrito será rechazado con la sugerencia de que el autor considere los comentarios y reenvíe el manuscrito revisado. Si el autor realiza los cambios y reenvía el manuscrito a RHE - JILAEH, éste será enviado a uno de los especialistas anónimos originales y a un nuevo experto en la materia. En esta revisión, los especialistas evaluarán los comentarios y cambios realizados por el autor después de haber introducido las críticas originales. En este caso, el proceso de revisión también es realizado de forma anónima. Si las revisiones del manuscrito reenviado son favorables, es probable que el manuscrito sea aceptado para publicación. 


\section{Adecuación de los artículos aceptados a las normas de edición}

Los autores de los artículos aceptados, en cualquier caso, deberán enviar una nueva versión adaptada al formulario de "normas de edición RHE-JILAEH» en un plazo nunca superior a los diez días.

\section{Corrección de pruebas de artículos aceptados para publicación}

Los autores podrán ser requeridos para la corrección de pruebas de imprenta, que habrán de ser devueltas en un plazo inferior a las 72 horas. No se permitirá la introducción de cambios sustanciales en las pruebas, quedando éstos limitados a la corrección de errores con respecto a la versión aceptada.

Nota importante: Todo artículo que no haya sido reelaborado y entregado antes de los seis meses desde la recepción de los informes de los especialistas deberá iniciar el proceso de revisión. 


\section{REVIEW PROCESS}

\section{Evaluation and review process for original documents and research notes}

In the interests of making the evaluation process for articles more transparent and more streamlined, RHE-JILAEH provides the following information for authors and evaluators regarding the evaluation and revision process from the arrival of the original through to publication of the article.

\section{Acknowledgment of receipt}

RHE-JILAEH promises to acknowledge receipt of an original manuscript within 10 days when the manuscript is received in electronic format.

\section{Initial Evaluation}

Every manuscript published in this review will be subjected of a external double blind peer review process. Manuscripts will be subjected to a "rapid review" by the editors or other specialists in the particular area who will usually be members of the Editorial Board. This review will focus on originality, relevance and scientific interest in order to decide whether the text is submitted to an external review. This decision will be communicated to authors within a maximum of 30 days from the acknowledgment of receipt of the manuscript.

\section{Full Evaluation}

If the initial evaluation is positive, RHE-JILAEH will send the manuscript to two or more external experts, following the peer review system, with the double-blind format. This does not imply that the article will be accepted. RHE-JILAEH will only take a decision after receiving at least two of the referees' reports. RHE-JILAEH encourages specialists to review manuscripts quickly (within a period of three to five weeks) to allow a final decision within three months of the decision to send a manuscript for full review.

In all the following cases authors will receive, on completion of the evaluation process, the anonymous comments made by the specialists.

\section{Acceptance and Conditional Acceptance}

If the reviews made by the anonymous specialists are favourable, the manuscript will usually be accepted on the condition that the author considers the comments and doubts expressed in the reviews. It is rare for an article to be accepted which requires absolutely no changes at all.

\section{Revise and resubmit}

If the majority of the above reviews is favourable but suggests revision and changes in the manuscript, the text will be rejected and the author will be invited to consider the specialists' comments and resubmit a revised document. If the author incorporates the suggested changes and resubmits the manuscript it will be sent to one of the original anonymous referees and to a new expert in the field. At this stage the specialists will evaluate the author's comments and the changes made as a result of the original criticisms. This review process is also anonymous. If the reviews of the resubmitted manuscript are favourable it is likely that the text will be accepted for publication.

\section{Adaptation of accepted articles to the publication norms}

Authors of accepted articles will be required to send a new version of the manuscript in which the RHE-JILAEH publication norms are applied within a maximum of 10 days. 


\section{Correction of proofs of articles accepted for publication}

Authors may be required to correct galley proofs which should be returned within 72 hours. Major changes are not permitted at this stage, the objective being simply to correct errors with respect to the accepted version.

Note: An article no resubmitted within six month from the referees' report will be considered a new submission. 